\title{
WYPISY ŹRÓDLOWE DO BIOGRAFII POLSKICH BISKUPÓW I OPATÓW Z CZASÓW RZECZYPOSPOLITEJ OBOJGA NARODÓW ORAZ NIEWOLI NARODOWEJ DOBY ZABORÓW (XVI - XIX W.)
}

\author{
(Cz. VIII)
}

W części czwartej kontynuowanego na łamach półrocznika „Archiwa, Biblioteki i Muzea Kościelne" cyklu Wypisów źródłowych zamieszczony został zbiór 110 ekscerptów z ksiąg czynności (acta actorum) kapituły katedralnej krakowskiej, funkcjonującej przy królewskiej świątyni na Wawelu, przynoszących informacje o instalacjach vel recepcjach do owego nobliwego grona duchownych ze stuleci XVII i XVIII, których nazwiska wpisane są w dzieje staropolskiego episkopatu (uwzględniono również postaci z grona ówczesnych opatów-komendatariuszy $)^{1}$. Obok posiadających same w sobie istotną dla historyka wartość danych natury chronologicznej, dopełniających $\mathrm{w}$ warstwie faktografii curriculum vitae konkretnych osób, ekscerpty te w szeregu przypadków zawierają również tzw. wywody szlachectwa (deductio nobilitatis) przyjmowanych do gremium kapitulnego duchownych, stanowiące wielce wartościowy materiał pod kątem badań genealogiczno-heraldycznych, które ostatnimi czasy przeżywają swój niejako renesans. $Z$ oczywistych względów ta kategoria źródeł od dawna tedy przykuwała uwagę badaczy, służąc za fundament przy opracowywaniu w szczególności słowników biograficznych poszczególnych kapituł katedralnych i kolegiackich, którego to rodzaju publikacji w dorobku rodzimej historiografii skądinąd nie ma jak dotąd wiele. O tym wszystkim była zresztą mowa we wstępie do tamtej edycji z roku 2006, w której wskazano również na istniejące wydawnictwa z owego zakre$\mathrm{su}^{2}$, przy czym w tym miejscu godzi się raz jeszcze ponowić postulat opublikowania Katalogu prałatów i kanoników włocławskich S. Chodyńskiego, które to opra-

${ }^{1}$ K. R. Prokop, Wypisy źródtowe do biografii polskich biskupów i opatów z czasów Rzeczypospolitej Obojga Narodów oraz niewoli narodowej doby zaborów (XVI-XIX w.), cz. 4, „Archiwa, Biblioteki i Muzea Kościelne”, 85 (2006) s. 305-377.

${ }^{2}$ Tamże, s. 306-309. W tym czasie wyszedł drukiem - nakładem Polskiej Akademii Umiejęt- 
cowanie - choć liczy sobie już sto lat - niezmiennie zachowuje dużą wartość, a jego wydanie wypełniłoby istotną lukę $\mathrm{w}$ badaniach nad prozopografią staropolskiego duchowieństwa kapitulnego ${ }^{3}$.

Wtedy również piszący te słowa nie omieszkał zwrócić uwagi, że w analogiczny sposób, jak to dane mu było uczynić w odniesieniu do świadectw dotyczących obecności późniejszych członków staropolskiego episkopatu w gronie kapituły katedralnej na Wawelu, wartało by również wydać drukiem ekscerpty tego rodzaju wpisów na temat instalacji czy recepcji duchownych, którzy następnie zostali biskupami (albo już wtenczas nimi byli), z akt płockiej kapituły katedralnej, tak samo jak dotąd nie posiadającej słownika biograficznego jej członków z czasów nowożytnych oraz najnowszych. Zarazem jednak doświadczenie uczy, że wysuwając jakiś postulat (również badawczy), najlepiej następnie samemu zatroszczyć się około jego zrealizowania (jeśli nie w pojedynkę, to przynajmniej biorąc na siebie rolę koordynatora zmierzających w określonym kierunku działań), aniżeli oczekiwać, iż ktoś inny przyjmie ową myśl za swoją i poświęci dla jej urzeczywistnienia potrzebny czas oraz wysiłek. Tak też w opublikowanej w roku 2009 księdze pamiątkowej Finis legis Christus, dedykowanej zajmującemu się w swoich badaniach również problematyką ustroju i organizacji kapituły katedralnej w Płocku w dobie przedrozbiorowej Ks. Prof. Wojciechowi Góralskiemu ${ }^{4}$, kreślący obecne słowa opublikował przeglądowy artykuł pt. Biskupi $w$ gronie pratatów i kanoników ptockiej kapituly katedralnej w XVII i XVIII stuleciu ${ }^{5}$ Obecnie nadszedł czas, by udostępnić ogółowi zainteresowanych podstawę źródłową,

ności - zapowiadany Katalog kanoników krakowskiej kapituły katedralnej w XVIII wieku B. Przybyszewskiego (Kraków 2009).

${ }^{3}$ Czynione przez piszącego te słowa próby przywrócenia owej pozycji do planu wydawniczego Polskiej Akademii Umiejętności w Krakowie, której nakładem tytuł ten miał ukazać się w okresie dwudziestolecia międzywojennego, napotkały nieoczekiwanie na raczej wstrzemięźliwą reakcję ze strony dyrekcji włocławskiego Archiwum Diecezjalnego. Jak w piśmie z daty: Włocławek, 15 I 2007 r. stwierdził stojący aktualnie na czele tej instytucji Ks. Prof. Witold Kujawski, ,prawdopodobnie nikt [już] nie będzie mógł odpowiedzieć na pytanie, dlaczego Ks. Jan Fijałek, w którym pokładał nadzieję Ks. Stanisław Chodyński, pracy tej nie wydał. Pamiętając, co mówił Ks. Stanisław Librowski i patrząc bliżej na tekst Ks. Chodyńskiego, należy przyznać, że przygotowanie go do druku według współczesnych wymogów oraz uzupełnienie i uaktualnienie przypisów, to praca na wiele czasu. To zapewne było powodem najpierw wstrzymania druku, po wojnie zaś stało się to już niemożliwe z powodu zmienionych warunków. Może kiedyś ktoś ze środowiska włocławskiego podejmie się to zrobić".

${ }^{4}$ Por. W. Góralski, Kapituła katedralna w Płocku XII-XVI w. Studium z dziejów organizacji prawnej kapitut polskich, Płock 1979; W. Góralski, Kapituła katedralna płocka. Zarys 900-letnich dziejów organizacji prawnej, Płock 2007; Statuty kapituly katedralnej w Ptocku z 1784 roku, wyd. W. Góralski, Lublin 1982. Dane bibliograficzne o innych publikacjach tego badacza, traktujących o dziejach i ustroju rzeczonego gremium kanoniczego, zainteresowany czytelnik znajdzie chociażby w zestawieniach zawartych w Księdze Pamiątkowej Wydziatu Prawa Kanonicznego ATK/UKSW 1954-2004, red. J. Wroceński, B. Szewczul i S. Kobiałka, Warszawa 2005, nr 6, s. 138-139, 149-156; nr 7, s. 197-217.

${ }^{5}$ K. R. Prokop, Biskupi w gronie prałatów i kanoników plockiej kapituly katedralnej w XVII i XVIII stuleciu, w: Finis legis Christus. Księga pamiatkowa dedykowana Księdzu Profesorowi Woj- 
która posłużyła autorowi tamtego opracowania do poczynienia uwidocznionych w owej publikacji ustaleń, przy czym chodzi właśnie o zawarte w księgach czynności (posiedzeń) płockiej kapituły katedralnej wpisy odnoszące się do instalacji czy też recepcji interesujących nas obecnie duchownych. Analogicznie, jak w przypadku owej wcześniejszej edycji, traktującej o katedrze na Wawelu, za terminus a quo przyjęto tu rok 1600, tym samym koncetrując uwagę na postaciach ze stuleci XVII i XVIII, co zresztą znalazło odzwierciedlenie w tytule wyżej wspomnianego opracowania. W tym kontekście godzi się też zwrócić uwagę, że dzieje rzeczonej kapituły do końca poprzedniego (tj. XVI) wieku, znalazły pełniejsze oświetlenie właśnie $\mathrm{w}$ publikacjach wyżej wspomnianego uczonego ${ }^{6}$, co dodatkowo uzasadnia przyjęcie przez nas wskazanej daty początkowej.

Za podstawę poniższej edycji źródłowej posłużyły zatem księgi czynności (posiedzeń) płockiej kapituły katedralnej z lat 1591-1796, których pełna specyfikacja uwidoczniona została poniżej. Niestety, w owym obejmującym przeszło dwa wieki „wycinku” dłuższej serii ksiąg, jest pojedyncza, kilkuletnia luka, związana z niedostępnością księgi odnoszącej się do okresu lat 1759/1760-1766/1767 (z analogicznych względów w odniesieniu do katedry na Wawelu przyszło nam niegdyś pominąć w opublikowanych ekscerptach okres lat 1684/1685-1689/1690). Zresztą nie jedyny to z możliwych braków, decydujących o pewnej niekompletności przedkładanego zbioru świadectw i opartego na nim zestawienia, gdy chodzi o obecność staropolskich biskupów w gronie rzeczonego kolegium kanoniczego, albowiem z jednej strony zdarzają się przypadki opuszczenia wpisów na temat przyjęć nowych członków kapituły, z drugiej zaś sam wydawca mógł przeoczyć jakieś pojedyncze spośród wymagających uwzględnienia świadectw. Nie zmienia to wszakże faktu, że prezentowany poniżej zbiór ekscerptów, traktujących o w łącznym ujęciu - sześćdziesięciu dwóch hierarchach, wpisanych w dzieje niejednej spośród diecezji ówczesnie rozległego państwa polsko-litewskiego, przynosi obfity zasób zaczerpniętych bezpośrednio z niepublikowanych dotychczas źródeł danych faktograficznych, które czy to uzupełniają i prostują wiadomości występujące już wcześniej w literaturze przedmiotu, albo też wprowadzają nowe ustalenia, nieobecne wcześniej w tzw. obiegu naukowym. Jak wszystkie dotychczas wydane w ramach serii Wypisów źródłowych (na równi z tymi, przewidzianymi do publikacji w dalszej kolejności), przygotowują one grunt pod opracowanie w przyszłości postulowanego słownika biograficznego (czyniącego zadość wymogom współczesnego warsztatu badawczego) staropolskiego episkopatu, obok którego ważnym pokrewnego charakteru przedsięwzięciem byłby również leksykon biograficzny ogółu opatów (zarówno klaustralnych, jak i komendatoryjnych) klasztorów mniszych na ziemiach polskich z czasów sprzed kasat doby porozbio-

ciechowi Góralskiemu z okazji siedemdziesiątej rocznicy urodzin, t. 1, red. J. Wroceński, J. Krajczyński, Warszawa 2009, s. 659-691.

${ }^{6}$ Zob. wyżej przyp. 4. Także: W. Góralski, Skład kapituly katedralnej płockiej do końca XVI w., „Studia Płockie”, 6 (1978) s. 124-153; W. Góralski, Prałatury w kapitule katedralnej płockiej do końca XVI w., „Częstochowskie Studia Teologiczne”, 6 (1978) s. 441-448; W. Góralski, Obsadzanie pratatur i kanonii w kapitule katedralnej w Płocku do końca XVI w., „Studia Płockie”, 7 (1979) s. $142-173$. 
rowej (o tym zresztą tak samo była mowa we wstępach do poprzednich części niniejszego cyklu).

$\mathrm{Z}$ tą również myślą w drugim bloku świadectw, zawartych $\mathrm{w}$ obecnie przedkładanym uwadze korzystających odcinku Wypisów źródłowych, pomieszczono zapiski informujące o instytucjach lub instalacjach łącznie dwudziestu jeden hierarchów z tychże samych stuleci (tj. XVII i XVIII) na kanonikaty lub prałatury w innych spośród istniejących w czasach staropolskich kapituł (Chełm/Krasnystaw, Jarosław, Lwów, Opatów, Przemyśl, Sandomierz, Skalbmierz, Tarnów, Włocławek) oraz na niektóre szczególnie eksponowane probostwa (prepozytury) - przeważnie z terenów ruskiej prowincji kościelnej (Jaworów, Kołomyja, Uchanie, obok tego również Klimontów czy Koziegłówki w diecezji krakowskiej). Tego rodzaju informacje wydają się szczególnie istotne przy próbie charakterystki ówczesnego „modelu” przebiegu tzw. kariery kościelnej, często bowiem przynależenie tychże eksponowanych postaci do pośledniejszej rangi kapituł (kolegiackich), podobnie jak fakt kumulowania przez biskupów pomniejszej rangi beneficjów (probostw), uchodzi uwadze autorów piszących o owych postaciach (dotyczy to w szczególności właśnie hierarchów z terenu metropolii lwowskiej, w przypadku których dochody tzw. stołu biskupiego przedstawiały się z reguły nadzwyczaj skromnie, z czego wynikała konieczność poszukiwania innych źródeł stałych funduszy). Nie od rzeczy będzie przy tym zwrócić uwagę, że wobec znacznego przetrzebienia rodzimych archiwaliów (również kościelnych) na skutek kataklizmów dziejowych oraz nieszcześć losowych, świadectw na temat tego rodzaju kumulowania beneficjów inkompatybilnych warto poszukiwać w zasobach archiwalnych Kurii Rzymskiej, gdzie mogły zachować się stosowne informacje o dyspensach dla duchownych zabiegających o prawo łączenia w swym ręku dwóch lub więcej funkcji (stanowisk) kościelnych. Bez próby pełniejszego ogranięcia tego zagadnienia trudno zaś silić się na jakiś całościowy opis problematyki źródeł dochodów i w konsekwencji kondycji materialnej członków staropolskiego episkopatu - w szczególności tych spośród nich, którym przyszło zajmować owe mniej eksponowane stolice rezydencjalne (a tym bardziej biskupów tytularnych), które to zagadnienie nie doczekało się jak dotychczas dogłębniejszej analizy w badaniach rodzimych historiografów. Stanowi to zarazem jeden więcej argument, przemawiający za celowością kontynuowania na łamach półrocznika „Archiwa, Biblioteki i Muzea Kościelne" zainicjowanego przed kilku laty cyklu Wypisów źródłowych, publikowane w ramach którego świadectwa władne są zainteresować badaczy zajmujących się różnorodnymi obszarami wiedzy o przeszłości.

Tytułem przypomnienia dla osób korzystających z publikowanego poniżej materiału, którym z jakichś względów trudno sięgnąć do wprowadzeń towarzyszącym poprzednim częściom Wypisów źródtowych, by zyskać potrzebną orientację w materii stosowanego przez wydawcę systemu oznaczeń i skrótów, podawane w nagłówku przy imieniu i nazwisku danego duchownego, po określeniu „,biskup” lub „arcybiskup”, nazwy geograficzne, to stolice tych diecezji, w których danemu hierarsze przyszło pełnił posługę (jeśli sukcesywnie w dwóch lub więcej kolejnych, zostały one wyliczone w porządku chronologicznym). Zapis nazwy stolicy biskupiej kursywą wskazuje, że hierarcha, do którego konkretny wpis się 
odnosi, nie był rządcą danej diecezji, a więc ordynariuszem, lecz ustanowionym do posługi w niej sufraganem (czy w ogólności biskupem pomocniczym, bowiem nie wszyscy spośród nich powoływani byli na fundowane sufraganie). Umieszczenie w nawiasie kwadratowym określenia „biskup” (,arcybiskup”) oraz owego wskazania na określoną diecezję oznacza, że w momencie włączenia do grona kanoników interesującej nas kapituły duchowny, którego rzecz dotyczy, nie był jeszcze członkiem episkopatu, lecz miał nim zostać dopiero w późniejszym czasie (tak było zresztą w przeważającej części spośród odnotowanych przypadków). Jeśli natomiast $\mathrm{w}$ nawiasie kwadratowym znalazły się wyłącznie kolejne nazwy stolic biskupich, za wyjątkiem pierwszej, wówczas tego rodzaju zapis wskazuje, iż dany hierarcha ją właśnie zajmował w momencie instalacji vel recepcji do składu kapituły, wszakże następnie awansował z owego biskupstwa na kolejne. Skądinąd zresztą są to tego rodzaju informacje, które zainteresowanej osobie łatwo zweryfikować w oparciu o literaturę przedmiotu i do niej też wypada odesłać w razie zaistnienia jakichś wątpliwości (w pewnym, z konieczności skromnym wyborze, wskazania na nią widnieją w towarzyszących poszczególnym ekscerptom przypisach, które wszakże mają charakter nie tyle komentarzy źródłowych, co wyłacznie swego rodzaju dopełnień natury bibliograficznej).

$* * * * *$

\section{Archiwum Diecezjalne w Plocku (ADP)}

ACapPloc 8 - Acta capituli cathedralis Plocensis ab anno 1591 ad annum 1604 [od k. 202v: rok 1600]

ACapPloc 8a-Acta capituli cathedralis Plocensis ab anno 1604 ad annum 1627 ACapPloc 8b - Acta capituli cathedralis Plocensis ab anno 1627 ad annum 1644 ACapPloc 9 - Acta capituli cathedralis Plocensis ab anno 1644 ad annum 1656 ACapPloc 10 - Acta capituli cathedralis Plocensis ab anno 1656 ad annum 1670 ACapPloc 11 - Acta capituli cathedralis Plocensis ab anno 1671 ad annum 1684 ACapPloc 12 - Acta capituli cathedralis Plocensis ab anno 1687 ad annum 1694 ACapPloc 13 - Acta capituli cathedralis Plocensis ab anno 1687 ad annum 1700 ACapPloc 14 [cz. II] - Acta capituli cathedralis Plocensis ab anno 1694 ad annum $1705^{7}$

ACapPloc 15 - Acta capituli cathedralis Plocensis ab anno 1706 ad annum 1714

\footnotetext{
${ }^{7}$ Wolumin ten składa się z dwóch części, z których pierwsza nie posiada paginacji, natomiast w drugiej numeracja kart rozpoczyna sie od 1 . Akta posiedzeń kapituły katedralnej płockiej, poczynając od sesji generalnej pro festo Sancti Sigismundi regis roku 1694, zawarte są w części drugiej. Część pierwsza to licząca czternaście niepaginowanych kart Metrica ordinatorum a Reverendissimo Domino D. Stanislao Starczewski, Dei et Apostolicae Sedis gratia episcopo Lacedaemoniensi, suffraganeo, abbate et canonico Plocensi, ad minores et maiores ordines in diversis locis et temporibus ad laudem et gloriam Omnipotentis Dei et Gloriosissimae Deiparae Virginis (wpisy z lat 1638-1643, przy czym pierwsze odnotowane w tej metryce święcenia, udzielone przez sufragana płockiego $\mathrm{S}$. Starczewskiego, odnoszą się do daty 18 XII 1638 r. [k. 3r]).
} 
ACapPloc 16 - Acta capituli cathedralis Plocensis ab anno 1714 ad annum 1725

ACapPloc 17 - Acta capituli cathedralis Plocensis ab anno 1725 ad annum 1739

ACapPloc 18 - Acta capituli cathedralis Plocensis ab anno 1739 ad annum 1749

ACapPloc 19 - Acta capituli cathedralis Plocensis ab anno 1749 ad annum 1753

ACapPloc 20 - Acta capituli cathedralis Plocensis ab anno 1753 ad annum 1759 [brak ksiegi ACapPloc 21 za lata 1759-1767] ${ }^{8}$

ACapPloc 22 - Acta capituli cathedralis Plocensis ab anno 1767 ad annum 1774 ACapPloc 23 - Acta capituli cathedralis Plocensis ab anno 1774 ad annum 1782 ACapPloc 24 - Acta capituli cathedralis Plocensis ab anno 1782 ad annum 1787 ACapPloc 25 - Acta capituli cathedralis Plocensis ab anno 1787 ad annum 1796

\section{Archiwum Archidiecezjalne w Lublinie (AALb)}

Rep.60 A 113 - Acta iudiciaria Illustrissimi Piasecki, episcopi [Chelmensis] ab anno 1642, die 12. Martii, ad annum 1645, diem 13. Februarii. [Item] Illustrissimi Pstrokonski, episcopi [Chelmensis] ab anno 1645, die 21. Septembris, ad annum 1655, diem 17. Martii

Rep.60 A 118 - Acta Illustrissimi Stanislai Swięcicki, episcopi [C]helmensis ab anno 1686, die 26. Augustii, ad annum 1691, diem 5. Decembris

Rep.60 A 136 - Acta curiae episcopalis [C]hełmensis annorum 1771, 1772, 1773, 1774, 1775, 1776, 1777, 1778 stante episcopatu Illustrissimi et Reverendissimi Domini, Domini Antonii Onuphrii de Okęcie Okęcki, Dei et Apostolicae Sedis gratia episcopi [C]hełmensis, Ordinis Aquilae Albae et S. Stanislai equitis

\section{Archiwum Archidiecezjalne w Przemyślu (AAPrz)}

841 - Acta venerabilis capituli ecclesiae collegiatae Iaroslaviensis a die secunda mensis Novembris anni millesimi sexcentesimi nonagesimi noni [1699-1737]

Archiwum Kapituły Przemyskiej, rkp VIII - Acta conclusionum venerabilis capituli ecclesiae cathedralis Praemisliensis a die 21. mensis Junii anno Domini 1686 inchoata usque ad diem 25. Januarii anni 1698 continuata

\section{Archiwum Archidiecezji Lwowskiej w Krakowie (AALw)}

K.K. 18[16] - Acta episcopalia Reverendissimi Domini Constantini comitis de Lipie Lipski, archiepiscopi Leopoliensis [1690-1693]

K.K. 19[17] - Protocollum actorum consistorii Leopoliensis sub officialatu Reverendissimi Domini Joannis Skarbek, episcopi Marrochiensis, suffraganei et custodis Leopoliensis ecclesiae metropolitanae [1695-1698]

K.K. 29[22] - Protocollon actorum officii administatorialis sede vacante archiepiscopatus Leopoliensis sub regimine Reverendissimi Domini Samueli de

${ }^{8}$ Zob.: Archiwum Diecezjalne w Płocku, sygn. ACapPloc 20, k. 190r („Desiderantur acta ab anno 1759 ad 1767, annorum octo"). Por. także: ADP, sygn. ACapPloc 64a - Praesentiae praelatorum et canonicorum capituli cathedralis Plocensis 1754-1768. 
Głowno Głowinski, episcopi Hebronensis, suffraganei, custodis metropolitani et generalis administratoris sede vacante [1736-1739]

\section{Archiwum Diecezjalne w Kielcach (ADK)}

II KS-3 - Liber tertius actorum, decretorum variarumque decisionum, tam in capitulis generalibus, quam extraordinaris particularibus, per Perillustres [et] Illustres praelatos et canonicos ecclesiae collegiatae Scarbimiriensis factarum ab anno 1700 ad annum 1771 inclusive conscriptus

\section{Archiwum Diecezjalne w Pelplinie (ADPelp)}

Archiwum Kapituły Katedralnej Chełmińskiej, sygn. B I 3 - Erectio et dotatio canonicatuum [nec non] receptiones, introductiones et resignationes canonicorum $[1257-1786]$

\section{Archiwum Diecezjalne w Tarnowie (ADT)}

KKol I 5 - Acta capitularia collegiatae Tarnoviensis ab anno 1619 ad annum 1735

KKol I 6 - Acta capitularia collegiatae Tarnoviensis ab anno 1736 ad annum 1784

\section{Archiwum Diecezjalne we Wloclawku (ADW)}

2-ABKP 28[44] - Protocollum actorum Illustrissimi, Excellentissimi et Reverendissimi Domini, Domini Christophori Antonii in Słupow Szembek, Dei et Apostolicae Sedis gratia episcopi Vladislaviensis et Pomeraniae [1721-1725]

\section{Archiwum Kurii Metropolitalnej w Krakowie (AKMK)}

AEp 43 - Acta actorum causarum spiritualium, obligationum, quiettationum, inscriptionum, cessionum, decimarum, testamentorum episcopatus Cracoviensis Illustrissimi et Reverendissimi Domini, Domini Martini Szyszkowski, Dei et Apostolicae Sedis gratia episcopi Cracoviensis, ducis Severiae, in annis 1624, 1625,1626 . Tomus tertius

AEp 100 - Prothocollon actorum vialium curiae Celsissimi Principis Illustrissimi et Reverendissimi Domini Caietani Ignatii Sołtyk, Dei et Apostolicae Sedis gratia episcopi Cracoviensis, ducis Severiae, anno quo incolumis ex captivitate rediit Domini MDCCLXXIII conscriptum [1773-1777] 
Bardziński Wojciech Ignacy [biskup (Włoctawek)]

\author{
kanonik płocki (recepcja 4 V 1676) \\ archidiakon płocki (instalacja 13 XII 1709) ${ }^{9}$
}

\begin{abstract}
ADP, ACapPloc 11, s. 94 (Capitulum generale pro festo Sancti Sigismundi anno Domini 1676: Perillustris Bardzinski receptus [est] in canonicatum doctoralem fundi Goctaw cum ea conditione, ut intra decursum duorum annorum procuret privilegium promotionis ad doctoratum Ss. Theologiae, protestante eodem de pacifica possessione; bez wywodu przodków); tamże, ACapPloc 15, k. 32v-33v (13 XII 1709: Installatio Perillustris et Reverendissimi Adalberti Bardzinski, Dei gratia episcopi Saraptensis, suffraganei Vladislaviensis, canonici Plocensis, ad archidiaconatum Plocensem post fata Perillustris et Reverendissimi Joannis Sampławski, illius ultimi et immediati possesoris, vacantem), $k$. $34 r$ (Capitulum generale pro festo $S$. Sigismundi 1710 r.: Iuramentum Perillustris Bardziński); zob. nadto: ADP, ACapPloc 16, k. $118 \mathrm{v}$ (12 II 1723: informacja o nadejściu wiadomości o śmierci biskupa Wojciecha Ignacego Bardzińskiego, sufragana i dziekana włoctawskiego, archidiakona ptockiego)
\end{abstract}

\title{
Bystrzycki Jowin Fryderyk [biskup (Warszawa)] koadiutor-kantor płocki (instalacja 30 VI 1786) ${ }^{10}$
}

ADP, ACapPloc 24, s. 669-671 (30 VI 1786: Installatio Perillustris Jovini Bystrzycki, canonici cathedralis Livoniae, ad coadiutoriam cantoriae cathedralis Plocensis [kantorem płockim byt ówcześnie miejscowy sufragan, biskup Wojciech Józef Gadomski]; bez wywodu przodków);

${ }^{9}$ S. Chodyński, Biskupi sufragani włocławscy, Włocławek 1906, s. 67-69 nr 29 („,ojcem jego był Jan Bardziński, herbu Habdank, pisarz ziemi łęczyckiej, matką Anna z Oporowa Miłońska, herbu Sulima"); Receptiones seu installationes ad episcopatum, praelaturas et canonicatus Ecclesiae Cathedralis Posnaniensis ab anno 1532 ad annum 1800, ed. R. Weimann, „Roczniki Towarzystwa Przyjaciół Nauk Poznańskiego” 35 (1909), s. 114-115 (,pater eius erat Joannes Vincentius de Bardzino Bardzynski, notarius terrestris Lanciciensis, de armis Abdank, mater Anna Milowska, de armis Sulima, avia paterna Anna Przerębska, de armis Nowina, avia materna Anna Konopacka, de armis Jastrzembiec"); Z. Szostkiewicz, Katalog biskupów obrządku łacińskiego przedrozbiorowej Polski, w: Sacrum Poloniae Millenium. Rozprawy - Szkice - Materiaty historyczne, t. 1, Rzym 1954, s. 410; P. Nitecki, Biskupi Kościoła w Polsce w latach 965-1999. Stownik biograficzny, Warszawa 2000², kol. 20 (,kanonik płocki (1676) oraz archidiakon pułtuski (1709)”); Prokop, Biskupi w gronie prałatów i kanoników, s. 675.

${ }^{10}$ A. J. Nowowiejski, Płock. Monografia historyczna, Płock $1931^{2}$ [reprint: 1990], s. 211, 303; L. Królik, Kapituła kolegiacka w Warszawie do końca XVIII wieku, Warszawa 1990, s. 185-186 nr 30; Encyklopedia wiedzy o jezuitach na ziemiach Polski i Litwy 1564-1995, oprac. L. Grzebień, Kraków 1996 [2004²], s. 82; P. Nitecki, Biskupi Kościoła w Polsce, kol. 47-48 („kanonik płocki (1795)"); Prokop, Biskupi w gronie prałatów i kanoników, s. 686-687; K. R. Prokop, Sukcesja święceń biskupich pasterzy Kościoła warszawskiego (1798-2007), „Prawo Kanoniczne”, 53 (2010) nr $1-2$, s. 341. 
tamże, ACapPloc 25, s. 829 (3 V 1793: Habilitatio Perillustris Bystrzycki, jako pratata kantora kapituly katedralnej w Płocku)

\section{3}

Całowański Stanisław [biskup (Płock)] ～kanonik płocki (recepcja 5 VI 1648)

ADP, ACapPloc 9, s. 300-301 (5 VI 1648: Receptus [est] in canonicum [Plocensem] fundi Drobnica, post mortem et obitum Illustris et Admodum Reverendi Domini olim Suentoslai Kobierzycki, eius praebendae ultimi et immediati possesoris, vacantis, Illustris et Admodum Reverendus Dominus Stanislaus Całowański; bez wywodu przodków)

\section{Charbicki Krzysztof [biskup (Wlocławek)]} archidiakon dobrzyński (recepcja 31 VIII 1635) ${ }^{12}$

ADP, ACapPloc 8a, s. 259-260 (31 VIII 1635: Receptio Reverendissimi Domini Charbicki ad archidiaconatum Dobrzinensem anno quo supra [1635], die Veneris ultima mensis Augusti; bez wywodu przodków)

\section{5}

\section{Czartoryski Teodor Kazimierz [biskup (Poznań)]}

prepozyt plocki (instalacja 17 XI 1724)

ADP, ACapPloc 16, k. 153v-155r (17 XI 1724: Installatio Celsissimi Principis Theodori Czartoryski, canonici Cracoviensis, ad praeposituram ecclesiae cathedralis Plocensis, post ascensum ex eadem praepositura ad episcopalem dignitatem Excellentissimi, Illustrissimi et Reve-

${ }^{11}$ Nowowiejski, Plock. Monografia historyczna, s. 80, 371, 427, 560, 562; Szostkiewicz, Katalog biskupów, s. 422; T. Żebrowski, Zarys dziejów diecezji płockiej, Płock 1976, s. 64 nr 17; Nitecki, Biskupi Kościoła w Polsce, kol. 49 (,kanonik (1641), wikariusz generalny i oficjał płocki, proboszcz w Płocku"); Prokop, Biskupi w gronie prałatów i kanoników, s. 671.

${ }^{12}$ Chodyński, Biskupi sufragani włocławscy, s. 50-51 nr 21 („ojciec jego [brak imienia] herbu Jastrzębiec, matka Jadwiga Tarnowska, siostra Jana, natenczas biskupa kujawskiego"); Nowowiejski, Płock. Monografia historyczna, s. 371; Szostkiewicz, Katalog biskupów, s. 423; Nitecki, Biskupi Kościoła w Polsce, kol. 49-50 (,kanonik płocki i archidiakon dobrzyński (1628)”); Prokop, Biskupi w gronie prałatów i kanoników, s. 668.

${ }^{13}$ Nowowiejski, Ptock. Monografia historyczna, s. 352, 354; Szostkiewicz, Katalog biskupów, s. 430; J. Nowacki, Dzieje archidiecezji poznańskiej, t. 2 - Archidiecezja poznańska w granicach historycznych i jej ustrój, Poznań 1964, s. 112; Nitecki, Biskupi Kościoła w Polsce, kol. 64 (,prepozyt płocki”); Prokop, Wypisy źródłowe do biografii polskich biskupów i opatów, cz. 4, s. 315-316 nr 5; tenże, Biskupi w gronie prałatów i kanoników, s. 681; B. Przybyszewski, Katalog kanoników krakowskiej kapituly katedralnej w XVIII wieku, Kraków 2009, s. 37. 
rendissimi Domini, Domini Andreae Stanislai Kostka in Zatuskie Załuski, nunc episcopi, ac pro illo tempore illius dignitatis praepositurae ultimi et immediati possessoris, vacantem)

Celsissimus Princeps Theodorus Czartoryiski, praepositus, nobilibus, catholicis, vitae probae ac legitimis parentibus, patre videlicet Celsissimo Principe Casimiro Czartoryiski, procancellario Magni Ducatus Lithuaniae, stemmatis Pogonia, matre Isabella Morsztynowna, stemmatis Leliwa, avia paterna Joanna Olęndzka, stemmatis Rawicz, avia materna Catharina Gordonowna, stemmatis Trium capitum aprorum alias Trzy głowy dzikow, procreatus est.

\title{
6
}

\author{
Czyżowski Zygmunt [biskup (Płock - Kamieniec - Łuck)] \\ kanonik płocki (recepcja 4 V 1648) \\ koadiutor-dziekan płocki (recepcja 26 I 1652) ${ }^{14}$
}

ADP, ACapPloc 9, s. 279-280 (4 V 1648: Receptus est Illustris et Admodum Reverendus Dominus Sigismundus Czyzowski, Sacrae Regiae Maiestatis secretarius, ad canonicatum fundi Grochow, post mortem et obitum Illustris et Admodum Reverendi Domini olim Alberti Woysza, immediati possesoris, vacantem; bez wywodu przodków); tamże, s. 517-522 (26 I 1652: Receptio Illustris et Admodum Reverendi Domini Sigismundi a Czyzow Czyzowski, canonici Plocensis [et] Varsaviensis, Sacrae Regiae Maiestatis secretarii, ad coadiutoriam decanatus Plocensis)

\section{7}

\begin{abstract}
Dambski Stanisław Kazimierz [biskup (Chełm/Krasnystaw - Łuck - Płock Włocławek - Kraków)]

kanonik plocki (recepcja 9 IX 1660) archidiakon ptocki (recepcja 24 IV 1664) ${ }^{15}$
\end{abstract}

${ }^{14}$ J. Korytkowski, Prałaci i kanonicy katedry metropolitalnej gnieźnieńskiej od roku 1000 aż do dni naszych, t. 1, cz. 2, Gniezno 1882, s. 188-190 (,syn Aleksandra z Czyżowa Czyżowskiego, herbu Topór, i Elżbiety Petejówny, córki Stefana, barona de Giers, herbu Lewart; babkę po ojcu miał Zofię Zborowską, córkę Mikołaja, starosty szydłowskiego, herbu Jastrzębiec, po matce Annę z Czechanowa Kiszczankę, wojewodziankę podlaską, herbu Dąbrowa”); Nowowiejski, Płock. Monografia historyczna, s. 211, 303, 562; Szostkiewicz, Katalog biskupów, s. 431; Żebrowski, Zarys dziejów diecezji płockiej, s. 64 nr 16; Królik, Kapituła kolegiacka w Warszawie, s. 186-187 nr 41; Nitecki, Biskupi Kościoła w Polsce, kol. 66 („,kanonik płocki”); K. R. Prokop, Sylwetki biskupów tuckich, Biały Dunajec - Ostróg 2001, s. 110-112; K. R. Prokop, Biskupi kamienieccy od średniowiecza do wspótczesności. Szkice biograficzne, Biały Dunajec - Ostróg 2007, s. 200-203; Prokop, Biskupi w gronie prałatów i kanoników, s. 671.

${ }^{15}$ Nowowiejski, Płock. Monografia historyczna, s. 67; Szostkiewicz, Katalog biskupów, s. 432; Żebrowski, Zarys dziejów diecezji płockiej, s. 57 nr 57; K. R. Prokop, Poczet biskupów krakowskich, Kraków 1999, s. 181-183; Nitecki, Biskupi Kościoła w Polsce, kol. 69-70; Prokop, Sylwetki biskupów tuckich, s. 115-118; Prokop, Biskupi w gronie pratatów i kanoników, s. 673-674. 
ADP, ACapPloc 10, s. 109-110 (9 IX 1660: Receptio Illustris et Admodum Reverendi Domini Stanislai Dampski [sic!], minorum ordinis clerici, ad canonicatum fundi Kaczorowo post mortem et obitum Illustris et Admodum Reverendi Domini olim Joannis Zadojski, canonici Posnaniensis [et] Plocensis), s. 201-202 (9 IX 1662: Receptio Illustris et Admodum Reverendi Domini Stanislai Dampski [sic!], canonici Plocensis, Sacrae Regiae Maiestatis secretarii, ad canonicatum fundi Strozewo), s. 281-282 (Receptus Perillustris et Admodum Reverendus Dominus Stanislaus de Lubraniec Dampski [sic!] in archidiaconum Plocensem, dignitatem post mortem et obitum Perillustris et Admodum Reverendi Domini olim Sebastiani Jawornicki, decani Luceoriensis, vacantem)

Praedictus Stanislaus Casimirus Dąmbski progenitus est nobilibus parentibus ac praedecessoribus clarissimis, videlicet Adamo Dampski [sic!], castellano Słonensis, stemmatis Godzięba, matre vero Elisabetha Iemielska, castellanida Kowalinensis, stemmatis Nieczuia, avia paterna Catharina Grabska, stemmatis Zubrza głowa, avia materna Sophia Krzycka, stemmatis Kotwicz.

\title{
8
}

\section{Dembowski Jan (starszy) [biskup (Włocławek)]}

kanonik plocki (instalacja 1 XII 1744)
kustosz ptocki (instalacja 14 VII 1752)

\begin{abstract}
ADP, ACapPloc 18, s. 175-176 (1 XII 1744: Installatio Perillustris et Reverendissimi Domini Joannis Dębowski, canonici Pultoviensis, ad canonicatum ecclesiae cathedralis Plocensis fundi Saczek in Radziwie post obitum Perillustris olim Adalberti Suffczynski, illius ultimi et immediati possessoris, vacantem); tamże, ACapPloc 19, k. 106v-107v (14 VII 1752: Installatio Perillustris Reverendissimi Domini Joannis Dembowski, collegiatae Pultoviensis decani, ad praelaturam custodiae ecclesiae cathedralis Plocensis post liberam resignationem Perillustris Domini Pauli Szczuka, cathedralis Culmensis et collegiatae Pultoviensis praepositi, illius ultimi et immediati possessoris, vacantem, ad praesentationem Sacrae Regiae Maiestatis, dicate praelaturae custodiae legitimi patroni et collatoris); tamże, ACapPloc 22, k. 11v-12 (na generalnej sesji kapituly «pro festo Nativitatis Beatissimae Virginis Mariae» wr. 1767 instalowany byt na koadiutora przy kustoszu płockim, biskupie Janie Dembowskim, sufraganie włocławskim, klerykniższychświęceńJoachim Dembowski, synpodkomorzegopłockiego TomaszaiJuliannyz Kampenhauzenów); zob. również: tamże, ACapPloc 25, s. 508-509 (6 VIII 1790), 514 nn.
\end{abstract}

Perillustris Joannes Dębowski, institutus canonicus Plocensis, nobilibus, catholicis, legitimis probaeque vitae parentibus, patre videlicet Floriano Dębowski, iudice terrestri Plocensi, stemmatis Jelita, matre Eva Ciechanowiecka, stemmatis Jastrzębiec, avia materna Hedvigi Komorowska, stemmatis Boza Wola, avia paterna Agnete Pniewska, stemmatis Jastrzębiec, procreatus est.

${ }^{16}$ Chodyński, Biskupi sufragani włocławscy, 75-77 nr 33; Nowowiejski, Płock. Monografia historyczna, s. 293, 341; Szostkiewicz, Katalog biskupów, s. 433; Nitecki, Biskupi Kościoła w Polsce, kol. 73 („kanonik pułtuski (1744) oraz kustosz płocki”); Prokop, Biskupi w gronie pratatów i kanoników, s. 683-684. 
Dembowski Mikołaj [biskup (Kamieniec)]

kanonik plocki (instalacja 16 III 1725)

kustosz płocki (instalacja 21 III 1738) ${ }^{17}$

ADP, ACapPloc 16, k. 157r-158v (16 III 1725: Installatio Perillustris et Admodum Reverendi Domini Nicolai Dęmbowski, minoris ordinis clerici, canonici Poltoviensis, ad canonicatum et praebendam fundi Otolinsko, post privationem Perillustris Zycinski, illius canonicatus et praebendae ultimi et immediati possessoris, vacantem); tamże, ACapPloc 17, s. $426-427$ (21 III 1738: Installatio Illustrissimi et Reverendissimi Domini Nicolai Dębowski, ecclesiarum cathedralis Cracoviensis canonici, Varsaviensis archidiaconi, Miechoviensis praepositi, supremi Regni notarii, ad praelaturam custodiae cathedralis Plocensis morte et obitu Perillustris olim Theodori Machczynski, illius ultimi et immediati possessoris, vacantem)

Perillustris Dominus Nicolaus Dęmbowski, provisus et institutus canonicus Plocensis, nobilibus, catholicis, legitimis ac vitae probae parentibus, patre videlicet Floriano Dęmbowski, stemmatis Jelita, matre Eva Ciechanowiecka, stemmatis Dąmbrowa, avia paterna Agnete Pniewska, stemmatis Jastrzębiec, avia materna Hedvigi Komorowska, stemmatis Boza Wola, procreatus est.

\section{0}

Denhoff Jan Kazimierz [biskup (Cesena), kardynał] dziekan plocki (recepcja 4 VI 1666) ${ }^{18}$

ADP, ACapPloc 10, s. 384-386 (4 VI 1666: Receptio Perillustris et Admodum Reverendi Domini Joannis Casimiri Dönhoff, canonici Varsaviensis, ad decanatum Plocensem)

Praedictus Perillustris et Admodum Reverendus Dominus Joannes Casimirus Dönhoff, canonicus Varsaviensis, progenitus est clarissimis progenitoribus suis, scilicet patre Magnifico Domino Theodoro Dönhoff, succamerario Regni, Urzędoviensi etc. capitaneo, matre vero Magnifica Domina Catharina Von Bessen, comitissa stemmatis Von Bessen, patris vero stemma Dönhoff, [s. 386] avia paterna Catharina Szeremberkowna, stemmatis Szeremberk, avia materna Aestera Rottmansdorffowna, comitissa stemmatis Rottmansdorff.

${ }^{17}$ Szostkiewicz, Katalog biskupów, s. 434; Królik, Kapituła kolegiacka w Warszawie, s. 187 nr 44; Nitecki, Biskupi Kościoła w Polsce, kol. 73 (,kanonik płocki”); Prokop, Wypisy źródtowe do biografii polskich biskupów i opatów, cz. 4, s. 317 nr 8; Prokop, Biskupi kamienieccy, s. 297-306; Prokop, Biskupi w gronie prałatów i kanoników, s. 681; Przybyszewski, Katalog kanoników krakowskiej kapituly katedralnej, s. 44-45.

${ }^{18}$ Monografia opactwa cystersów we wsi Mogile, Kraków 1867, s. 125-129 nr 8; Szostkiewicz, Katalog biskupów, s. 434; K. R. Prokop, Polscy kardynałowie, Kraków 2001, s. 133-143; Prokop, Biskupi w gronie prałatów i kanoników, s. 674. 
Denhoff Jerzy Albrecht biskup (Przemyśl) [(- Kraków)]
prepozyt ptocki (instalacja 2 III [IV? $\left.]^{19} 1693\right)^{20}$

ADP, ACapPloc 13, s. 194-196 (2 III [IV?] 1693: Installatio Illustrissimi ac Reverendissimi Domini Georgii Albrachti comitis Denhoff, Dei et Apostolicae Sedis gratia episcopi Premisliensis, ad praeposituram cathedralem Plocensem post ascensum Excellentissimi, Illustrissimi ac Reverendissimi Domini Andreae in Załuskie Zaluski, eadem gratia episcopi Plocensis, in sedem eiusdem episcopatus Plocensis)

\section{2}

Firlej Henryk (starszy) [arcybiskup (Luck - Płock - Gniezno)]
prepozyt płocki (recepcja 27 XI 1607)21

ADP, ACapPloc 8a, k. 67v-68v (Anno Domini MDC septimo, die vero XXVII Novembris. Receptus in praepositum Plocensem Reverendus Dominus Henricus Firley; recepcja referendarza koronnego i scholastyka krakowskiego Henryka Firleja na prepozyturę płocka, wakująca "per evectionem ad dignitatem episcopalem Posnaniensem Reverendissimi Domini D. Andreae Opalinski de Bnin»; bez wywodu przodków); zob. również: tamże, k. 263-265v (7 III 1617: Actus receptionis Illustrissimi et Reverendissimi Domini Henrici Firley de Dąmbrowica in episcopum Plocensem), $284 r$ (30 IV 1618: Ingressus Illustrissimi et Reverendissimi in Christo Patris Domini, Domini Henrici Firley de Dąmbrowica ad sponsam cathedralis Plocensis, ultima mensis Aprilis MDCXVIII)

\section{3}

\section{Firlej Henryk (młodszy) [biskup (Przemyśl - Poznań)]} kanonik plocki (recepcja 3 IV 1620) kanclerz płocki (instalacja $22 \times 1620)^{22}$

${ }^{19}$ Wątpliwość w odniesieniu do daty miesięcznej wiąże się z okolicznością, iż jakkolwiek stosowny wpis jest przyporządkowany do daty secunda Martii, to wszakże poprzedzają go akta sesji kapitulnej z daty sexta Martii.

${ }^{20}$ Receptiones seu installationes, s. 114; W. Sarna, Biskupi przemyscy obrządku łacińskiego, cz. 2 - (1624-1900), Przemyśl 1910, s. 390-394; Szostkiewicz, Katalog biskupów, s. 434-435; Prokop, Poczet biskupów krakowskich, s. 184-186; Nitecki, Biskupi Kościoła w Polsce, kol. 73-74; Prokop, Wypisy źródłowe do biografii polskich biskupów i opatów, cz. 4, s. $318 \mathrm{nr}$ 10; Prokop, Biskupi kamienieccy, s. 237-243; Prokop, Biskupi w gronie prałatów i kanoników, s. 676-677.

${ }^{21}$ J. Wiśniewski, Katalog prałatów i kanoników sandomierskich od 1186-1926 r. tudzież sesje kapituly sandomierskiej od 1581 do 1866 r., Radom 1926, s. 61; Nowowiejski, Płock. Monografia historyczna, s. 62, 354; Szostkiewicz, Katalog biskupów, s. 446; Żebrowski, Zarys dziejów diecezji płockiej, s. 56-57 nr 51; Nitecki, Biskupi Kościoła w Polsce, kol. 99 (,,proboszcz płocki”); K. R. Prokop, Arcybiskupi gnieźnieńscy w tysiącleciu, Kraków 2000, s. 202-204; Prokop, Sylwetki biskupów luckich, s. 74-77; Prokop, Biskupi w gronie prałatów i kanoników, s. 664.

${ }^{22}$ Receptiones seu installationes, s. 95; Sarna, Biskupi przemyscy, cz. 2, s. 281-291; Szostkie- 
ADP, ACapPloc 8a, k.373v-374r (3 IV 1620: Receptio ad canonicatum et praebendam Plocensem fundi Ptońsko nuncupatum Illustris et Admodum Reverendi Domini Henrici Firley de Dabrowicza, clerici dioecesis Cracoviensis; bez wywodu przodków), 333r-v (9 IX 1620: Emissio professionis fidei cum praestitione iuramenti per Illustrem et Reverendum Dominum Henricum Firley, canonicum), 360r-361r (22 X 1620: Installatio Reverendi Domini Henrici Firley ad dignitatem cancellariatus ecclesiae cathedralis Plocensis ex libera ipsius resignatione seu alias translatione in abbatiam Cervenensem Reverendissimum Dominum Nicolaum Szyszkowski)

\section{4}

\section{Gadomski Wojciech Józef [biskup (Ptock)]}

kantor płocki (recepcja 2[?] $]^{23}$ V 1758) ${ }^{24}$

ADP, ACapPloc 20, k. 163r-v (16 XII 1757: Installatio ad cantoriae praelaturam. Petitum Perillustris Gadomski, provisi apostolici, in ordine ad installandum ad praelaturam cantoriae in hac cathedra, capitulum praesens, inhaerendo decretis generalis capituli, quod provisi apostolici nonnisi in generalibus capitulis installari debent, huiusmodi installationem ac petitum praedicti Perillustri Gadomski ad futurum generale capitulum distulit), 167r-168r (Capitulum generale pro festo Sancti Sigismundi anno Domini 1758: Installatio Perillustris cantoris Gadomski. Perillustris Dominus Adalbertus Josephus Gadomski, in Seminario Dioecesano Pultoviensi director, Sacrae Theologiae examinator synodalis, ad praelaturam cantoriae huius cathedrae, morte et obitu olim Illustrissimi ac Reverendissimi Domini Joannis Krasinski, episcopi Lorimensis, suffraganei Chetmensis, dictae cantoriae ultimi et immediati possessoris, vacantem, institutus [est]); zob. również: tamże, ACapPloc 25, s. 619 (23 VI 1791)

Perillustris Gadomski nobilibus, catholicis, legitimis parentibus, patre videlicet Martino Gadomski, stemmatis Rola alias Trzy Kroie, matre Eva Grabowska, stemmatis Pobok, avia paterna Hedvigi Gadomska, stemmatis Rola, avia materna Anna Niezwoiewska, stemmatis Gołabok seu Hołobok, progenitus est.

\section{5}

Garnysz Maciej Grzegorz [biskup (Włocławek [Gdańsk] - Chełm/Krasnystaw)] kanonik płocki (instalacja 17 VIII 1770)25

wicz, Katalog biskupów, s. 446-447; Nowacki, Dzieje archidiecezji poznańskiej, t. 2, s. 106; Nitecki, Biskupi Kościoła w Polsce, kol. 100; Prokop, Biskupi w gronie prałatów i kanoników, s. 665-666.

${ }^{23}$ Brak pewności co do daty dziennej.

${ }^{24}$ Nowowiejski, Plock. Monografia historyczna, wg indeksu; Szostkiewicz, Katalog biskupów, s. 449; Żebrowski, Zarys dziejów diecezji płockiej, s. 64 nr 24; Nitecki, Biskupi Kościoła w Polsce, kol. 107; Prokop, Biskupi w gronie prałatów i kanoników, s. 684.

${ }^{25}$ Chodyński, Biskupi sufragani włocławscy, s. 88-90 nr 2; W.F. Pawelec, Biskupstwo chetmskie, cz. [6], „Wiadomości Diecezjalne Lubelskie” 16 (1934) nr 11, s. 399 nr 53; Szostkiewicz, Katalog biskupów, s. 450; Nitecki, Biskupi Kościoła w Polsce, kol. 109 („,kanonik płocki”); Prokop, Biskupi w gronie prałatów i kanoników, s. 686. 
ADP, ACapPloc 22, k. 80v-81r (17 VIII 1770: Installatio Perillustris Reverendissimi Mathiae Garnysz, utriusque iuris doctoris, ecclesiarum cathedralium Vladislaviensis et Plocensis canonici, collegiatae Krusviciensis custodis, ad canonicatum fundi paenitentiariae in hac cathedra post liberam resignationem Illustrissimi ac Reverendissimi Cypriani Wolicki, episcopi Synopensis, suffraganei Pomeraniae, illius ultimi et immediati possessoris, vacantem; bez wywodu przodków)

\section{6}

Gembicki Piotr biskup (Przemyśl) [(- Kraków)] prepozyt plocki (recepcja 13 VIII 1638)26

ADP, ACapPloc 8b, s. 428-430 (Anno Domini millesimo sexcentesimo trigesimo octavo, die Veneris decima tertia mensis Augusti. Receptio Reverendissimi Domini Petri Gembicki, Dei et Apostolicae Sedis gratia episcopi Praemisliensis, supremi Regni cancellarii, praepositi Miechoviensis, ad praeposituram cathedralem Plocensem, post ascensionem et evectionem Illustrissimi et Reverendissimi Domini Joannis Lipski, eiusdem dignitatis et praepositurae ultimi possessoris, in archiepiscopatum Ecclesiae Metropolitanae Gnesnensis, vacantem)

[Quatuor testes] recognoverunt memoratum Illustrissimum et Reverendissimum Dominum [Petrum Gembicki], episcopum Praemysliensem, ex utroque parente nobili et illustrium familiarum progenitum esse, patre videlicet Generoso Ioanne Gęmbicki, palatinatus Posnaniensis pocillatore, armorum Nałęcz, matre Generosa Catherina [s. 430] Czielecka de armis Zaremba, avia paterna Generosa Dorothea Niniska, stemmatis Nałęcz, avia materna Generosa Margaretha Galewska de stemmate Wierusz.

\section{7}

Gembicki Wawrzyniec [arcybiskup (Chełmża - Włocławek - Gniezno)]

kustosz plocki (recepcja 23 I 1599) ${ }^{27}$

${ }^{26}$ J. Korytkowski, Prałaci i kanonicy katedry metropolitalnej gnieźnieńskiej, t. 2, Gniezno 1883, s. 52-57; Sarna, Biskupi przemyscy, cz. 2, s. 308-323; H. E. Wyczawski, Biskup Piotr Gembicki 1585-1657, Kraków 1957, s. 44 („W r. 1638 został prepozytem kapituły płockiej - po ustąpieniu Jana Lipskiego, nominata gnieźnieńskiego. Instalował się na to probostwo 13 VIII 1638 r. przez prokuratora, którym wyznaczył Piotra Poniatowskiego, dziekana pułtuskiego"); Szostkiewicz, $\mathrm{Ka}$ talog biskupów, s. 452-453; Stownik biograficzny kapituly warmińskiej, oprac. zbior., Olsztyn 1996, s. 67 (A. Kopiczko); Prokop, Poczet biskupów krakowskich, s. 169-173; Nitecki, Biskupi Kościoła w Polsce, kol. 113 (,prepozyt płocki”); Prokop, Wypisy źródłowe do biografii polskich biskupów i opatów, cz. 4, s. $321 \mathrm{nr}$ 14; Prokop, Biskupi w gronie prałatów i kanoników, s. 669.

${ }^{27} \mathrm{~J}$. Korytkowski, Arcybiskupi gnieźnieńscy, prymasowie i metropolici polscy od roku 1000 aż do roku 1821 czyli do połaczenia arcybiskupstwa gnieźnieńskiego z biskupstwem poznańskim, t. 3, Poznań 1889, s. 636nn; Receptiones seu installationes, s. 67 (,probata nobilitate ex patre Paulo Gembiczki, districtus Posnaniensis, de armis Nalęcz, matre Łoweczka sive Nininska, de armis Nalęcz, matre patris Chlebowska, de armis Rosa, matre matris Chibska, de armis Jastrzebiecz"); 
ADP, ACapPloc 8, k. 179r-181r (Anno Domini millesimo quingentesimo nonagesimo nono, die 23. Januarii. Receptio Admodum Reverendi Domini Laurentii Gębiczky, praepositi Cracoviensis, Sacrae Regiae Maiestatis secretarii, ad custodiam ecclesiae Plocensis, morte et obitu Reverendi olim Stanislai Crassiczki, archidiaconi Cracoviensis, vacantem; bez wywodu przodków, lecz sama tylko uwaga: Recepta probatione nobilitati ipsius Domini Gębicky, prout moris est); zob. również: tamże, $k$. $221 r$-v (Anno Domini millesimo sexcentesimo, die 24. mensis Novembris. Receptio Reverendi Domini Petri Gwiazdowsky, canonici Cracoviensis, ad custodiam Plocensem [vacantem] per liberam resignationem Admodum Reverendi Domini Laurentii Gębiczky, nominati episcopi Culmensis, praepositi Cracoviensis et secretarii maioris Regni).

\title{
18
}

\section{Gomoliński Jan Pawet [biskup (Kijów)] kanonik płocki (instalacja 4/5 X 1691) archidiakon płocki (instalacja 19 XII 1692)28}

\begin{abstract}
ADP, ACapPloc 12, b.p. (5 X 1691: Installatio Perillustris Joannis Gomolinski ad canonicatum Plocensem post mortem et obitum Perillustris Admodum Reverendi olim Adami Krasinski); tamże, ACapPloc 13, s. 108-109 (4 X 1691: Installatio Perillustris Joannis Gomolinski ad canonicatum et praebendam fundi Peczek dictam Plocensem), s. 189-190 (19 XII 1692: Installatio ad archidiaconatum Plocensem post mortem et obitum Perillustris, Reverendissimi Domini olim Ludovici Tholibowski, suffraganei Plocensis, vacantem, Perillustris et Admodum Reverendi Joannis Gomolinski, canonici ecclesiae cathedralis Plocensis) [postapil nastęnie na pratature scholastyka w kapitule katedralnej w Ptocku]
\end{abstract}

[Perillustris Joannes Gomolinski installatus est] audita deductione et visa nobilitatis suae [documentis] ex patre Magnifico Domino Alexandro Gomolinski, castellano Rosprzensis, stemmatis Kopie trzy seu [pozostawiono puste miejsce] dictae, et Magnifica Teressia Lipska, matre sua, stemmatis Grabie alias [pozostawiono puste miejsce], et Magnifica Domina Dorothea Cielecka, avia matris suae, stemmatis Lew w murze alias [Zaremba] [pozostawiono puste miejsce], et ex Magnifica Domina Elisabetha Kobielska, avia patris, stemmatis Roza alias [pozostawiono puste miejsce].

Diecezja chetmińska. Zarys historyczno-statystyczny, oprac. zbior., Pelplin 1928, s. 41 nr 27; Szostkiewicz, Katalog biskupów, s. 453; Nitecki, Biskupi Kościoła w Polsce, kol. 113-114; Prokop, Arcybiskupi gnieźnieńscy, s. 199-201; Prokop, Biskupi w gronie prałatów i kanoników, s. 663.

${ }^{28}$ Szostkiewicz, Katalog biskupów, s. 457; M. Borkowska, $Z$ dziejów opactwa cystersów w Wachocku, Kielce 1998, s. 127-128; Nitecki, Biskupi Kościoła w Polsce, kol. 124; K. R. Prokop, Biskupi kijowscy obrzadku tacińskiego XIV-XVIII w. Szkice biograficzne, Biały Dunajec - Ostróg 2003, s. 105-111; Prokop, Biskupi w gronie prałatów i kanoników, s. 676. 


\title{
19
}

\section{Kanigowski Franciszek [biskup (Włocławek)]} kanonik płocki (instalacja 16 VIII 1715) kanclerz płocki (instalacja 4 VII 1732, powtórnie 6 IV 1735)29

\begin{abstract}
ADP, ACapPloc 16, k. 6v-7r (16 VIII 1715: Installatio Reverendi Domini Francisci Kanigowski, praepositi Zagrobensis, ad canonicatus et praebendam fundi Kostrogay in ecclesia cathedrali Plocensis post liberam resignationem Perillustris Stanislai Szpinek, canonici Plocensis, praepositi Badkoviensis, illorum canonicatus et praebendae ultimi et immediati possessoris, vacantem; bez wywodu przodków); tamże, ACapPloc 17, s. 250-251 (4 VII 1732: Installatio Perillustris et Reverendissimi Domini Francisci Kanigowski, Vladislaviensis et Plocensis cathedralis canonici, ad cancellariatum in ecclesia cathedrali Plocensi post liberam resignationem Perillustris et Reverendissimi Domini Adalberti Strzeszewski, cancellarii, illius dignitatis cancellariatus ultimi et immediati possessoris, vacantem), s. 362 (6 IV 1735: Installatio Perillustris et Reverendissimi Domini Francisci Kanigowski, ecclesiarum cathedralium Cuiaviensis scholastici, Plocensis canonici, ad cancellariatum eiusdem ecclesiae cathedralis Plocensis post mortem et obitum Perillustris et Reverendissimi olim Adalberti Strzeszewski, illius ultimi et immediati possessoris, vacantem) [postapit nastepnie na prałaturę archidiakona płockiego]; zob. nadto: tamże, ACapPloc 20, k. 42v-45r (28 IX 1753: Ingrossatio manifestationis contra coadiutoriam praelaturae archidiaconiae Plocensis ex parte Reverendissimi capituli cathedralis Plocensis), 53v-54r (Coadiutoria archidiaconiae), 90r-91r (jako archidiakon płocki biskup F. Kanigowski, wtenczas już sufragan włoctawski i prepozyt tamtejszej kapituly katedralnej, podją u Stolicy Apostolskiej starania o przydanie mu koadiutora w osobie Franciszka Małowieskiego, kuratusa w Brześciu Kujawskim, nie baczac na stanowisko w owym względzie kapituly płockiej, co wywołalo oficjalny protest z jej strony), 108v-109v (Capitulum generale pro festo Nativitatis Gloriosissimae Virginis Mariae anno Domini 1755: Installatio Perillustris Francisci Małowieski, canonici collegiatae Crusviciensis, ad coadiutoriam archidiaconiae Plocensis)
\end{abstract}

\section{0}

\section{Krasiński Adam Stanisław [biskup (Kamieniec)]}

$$
\text { kanonik płocki (instalacja } 19 \text { VIII 1740) }{ }^{30}
$$

ADP, ACapPloc 18, s. 32-34 (19 VIII 1740: Installatio Perillustris Adami Krasinski ad canonicatum ecclesiae cathedralis Plocensis fundi Kaczorowo post ascensum Perillustris et Reveren-

${ }^{29}$ Chodyński, Biskupi sufragani włocławscy, $72-74$ nr 32 („,ojciec jego Jan, herbu Bzura czyli Lis, matka Marianna Dąbrowska"); Nowowiejski, Płock. Monografia historyczna, s. 524, 527, 529; Szostkiewicz, Katalog biskupów, s. 482; Nitecki, Biskupi Kościoła w Polsce, kol. 193 („kustosz i kanclerz płocki”); Prokop, Biskupi w gronie prałatów i kanoników, s. 680-681.

${ }^{30}$ Korytkowski, Prałaci i kanonicy katedry metropolitalnej gnieźnieńskiej, t. 2, s. 358-360; Szostkiewicz, Katalog biskupów, s. 492-493; Nitecki, Biskupi Kościoła w Polsce, kol. 224 („,kanonik płocki”); Prokop, Biskupi kamienieccy, s. 306-319; Prokop, Biskupi w gronie prałatów i kanoników, s. 682-683. 
dissimi Domini Casimiri Rokitnicki primitive ad archidiaconatum Dobrynensem, illius ultimi et immediati possessoris, vacantem)

Perillustris Adamus Krasinski nobilibus, legitimis probaeque vitae parentibus, patre videlicet M[agnifico] Joanne Krasinski, stemmatis Korwin, matre M[agnifica] Teressia Sołtykowna, stemmatis Sołtyk, avia paterna G[enerosa] Sophia Garczynska, stemmatis [pozostawiono puste miejsce na wpisanie nazwy herbu], avia materna G[enerosa] Sophia Micielska, stemmatis Prawdzic, progenitus est.

\section{1}

Krasiński Jan [biskup (Chetm/Krasnystaw)]

kantor plocki (instalacja $4[?]^{31}$ V 1731) ${ }^{32}$

ADP, ACapPloc 17, s. 204-205 (Capitulum generale pro festo S. Sigismundi regis anno Domini 1731, a die $4^{\text {ta }}$ Mai cum continuatione dierum sequentium: Installatio Perillustris et Reverendissimi Ioannis Krasinski, canonici Varmiensis, ad praelaturam cantoriae cathedralis Plocensis post electionem et ascensum Perillustris Mdzewski ad archidiaconatum in eadem ecclesia, vacantem; bez wywodu przodków), s. 227 (Capitulum generale pro festo Nativitatis Beatissimae Virginis Mariae anno Domini 1731 cum continuatione dierum sequentium: Inductio testium ad probandam nobilitatem Perillustris Joannis Krasinski)

Perillustris Joannes Krasinski, praelatus cantor, nobilibus, catholicis vitaeque probae parentibus procreatus est, patre videlicet Jacobo Krasinski, castellano Ciechanoviensi, stemmatis Korwin, matre Generosa Barbara Kuklinska, dapiferi Ciechanoviensis [filia], stemmatis Prawdzic, avia paterna Catharina Młocka, stemmatis Prawdzic, avia materna Eva Wyszlowna [Wipslowna?], stemmatis Rogala.

\section{Leszczyński Andrzej [arcy]biskup (Kamieniec) [(Luck - Gniezno)]}

prepozyt płocki (recepcja 1 VI 1646) ${ }^{33}$

31* Brak pewności co do daty dziennej.

${ }^{32}$ W. F. Pawelec, Biskupstwo chetmskie, cz. [7], „Wiadomości Diecezjalne Lubelskie”, 17 (1935) nr 1, s. 23 nr 9 („,był kanonikiem płockim”); Szostkiewicz, Katalog biskupów, s. 493; Stownik biograficzny kapituly warmińskiej, oprac. zbior., Olsztyn 1996, s. 131-132 (A. Kopiczko); Nitecki, Biskupi Kościoła w Polsce, kol. 226 (,po święceniach (1721) archidiakon kapituły płockiej”); Prokop, Biskupi w gronie prałatów i kanoników, s. 682.

33 J. Korytkowski, Arcybiskupi gnieźnieńscy, prymasowie i metropolici polscy, t. 4, Poznań 1891, s. 57nn; Diecezja chetmińska, s. 43 nr 33; Szostkiewicz, Katalog biskupów, s. 498; H. Folwarski, Poczet opatów klasztoru kanoników regularnych w Czerwińsku, „Nasza Przeszłość” 6 (1957), s. 32-34; Nitecki, Biskupi Kościoła w Polsce, kol. 244-245; Prokop, Arcybiskupi gnieźnieńscy, s. 215-217; Prokop, Wypisy źródłowe do biografii polskich biskupów i opatów, cz. 4, s. $332 \mathrm{nr}$ 34; Prokop, Biskupi kamienieccy, s. 179-187; Prokop, Biskupi w gronie pratatów i kanoników, s. 671. 
ADP, ACapPloc 9, s. 146 (1 VI 1646: Receptio Illustrissimi et Reverendissimi Andreae Lesczynski, episcopi Camenecensis, nominati Culmensis, Regni vicecancellarii, ad praeposituram ac dignitatem in ecclesia cathedrali Plocensi post liberam resignationem Illustrissimi ac Reverendissimi Domini Stanislai Pstrokonski, episcopi Chetmensis, illius ultimi et immediati possessoris, vacantem; bez wywodu przodków)

Leszczyński Bogusław Franciszek [biskup (Łuck)] prepozyt płocki (recepcja 8 IX 1659, ponowienie 9 IX 1662)

ADP, ACapPloc 10, s. 67-68 (8 IX 1659: Receptio Perillustris et Admodum Reverendi Domini Boguslai comitis de Leszno Leszczynski, minorum ordinum clerici dioecesis Vratislaviensis, ad praeposituram ecclesiae cathedralis Plocensis post liberam resignationem Illustrissimi et Reverendissimi Domini Andreae Trzebicki, episcopi Cracoviensis), s. 192-201 (9 IX 1662: Innovatio receptionis Perillustris et Reverendissimi Domini Boguslai Francisci de Leszno Lesczynski ad praeposituram cathedralem Plocensem cum dispensatione Sanctae Sedis Apostolicae)

Praefatus Perillustris et Admodum Reverendus Boguslaus comes de Leszno Lesczynski progenitus est claris ac nobilibus parentibus, videlicet patre Boguslao comite de Leszno Lesczynski, vicecancellario Regni, stemmatis Żubrza głowa, matre vero Anna Dynofowna [sic!], palatinide Siradiensi, armorum Wieprzowa głowa, avia paterna Anna Radzyminska, stemmatis Brodzic [Brodziec] alias Trzy Krzyże, avia materna Alexandra Koniecpolska, stemmatis Pobok.

\section{4}

Leszczyński Jan [biskup (Kijów - Chełmża)]

kanonik plocki (recepcja 20 XII 1647) ${ }^{35}$

ADP, ACapPloc 9, s. 262-263 (20 XII 1647: Actus receptionis Illustris et Admodum Reverendi Domini Joannis a Leszno Lesczynski, Sacrae Regiae Maiestatis secretarii, ad canonicatum fundi Rogotworsk); tamże, s. 264 (Iuramentum Domini Lesczynski)

[Quatuor testes] recognoverunt Illustrem et Admodum Reverendum Dominum Joannem Lesczynski ex nobili et illustri prosapia esse progenitum, patre videlicet Illustri et Magnifico Domino olim Venceslao de Leszno Lesczynski, supremo Re-

${ }^{34}$ Szostkiewicz, Katalog biskupów, s. 498; Folwarski, Poczet opatów klasztoru kanoników regularnych w Czerwińsku, 38-40; Nitecki, Biskupi Kościoła w Polsce, kol. 245 (,prepozyt płocki (1658)"); Prokop, Sylwetki biskupów luckich, s. 121-125; Prokop, Biskupi w gronie pratatów i kanoników, s. 673.

${ }^{35}$ Diecezja chetmińska, s. 43 (po numerze 34); Szostkiewicz, Katalog biskupów, s. 498; Nitecki, Biskupi Kościoła w Polsce, kol. 245-246; Prokop, Biskupi kijowscy, s. 79-83; Prokop, Biskupi w gronie prałatów i kanoników, s. 671. 
gni cancellario, ex armis Wieniawa, matre vero [brak imienia] de Rozrazew Rozrazewska, armorum Doliwa, avia paterna Catherina Korzbokowna, stemmatis Korzbog, avia materna Anna de Potulice Potulicka, stemmatis Grzymała.

\section{5}

\section{Leżeński Tomasz [biskup (Chełm/Krasnystaw - Łuck)] \\ kanonik płocki (recepcja 2 IX 1634)}

ADP, ACapPloc 8b, s. 212-214 (Anno Domini MDCXXXIV, die secunda mensis Septembris. Receptio Reverendi Domini Thomae Lezenski, Sacrae Regiae Maiestatis secretarii, ad canonicatum et praebendam fundi Kraikowo in ecclesia cathedrali Plocensi post mortem et obitum Reverendi olim Pauli Koludzki vacantem)

Dominus canonicus [Thomas Leżeński] ex utroque parente est [nobilis] progenitus, patre videlicet Generoso Gregorio Lezenski ex armis Nalęcz, matre vero Generosa Anna Drohoiewska ex armis Korczak, avia ex patre Generosa Anna Męcinska ex armis Roza, avia ex matre Dorothea Ostrowska ex armis Korczak.

Lipski Andrzej [biskup (Łuck - Włocławek - Kraków)] scholastyk plocki $31 \mathrm{~V} 1600^{37}$

ADP, ACapPloc 8, k. 208r-209r (Anno Domini millesimo sexcentesimo, die ultima mensis Maii. Receptio Admodum Reverendi Domini Andreae Lipsky in scholasticum ecclesiae Plocensis post liberam resignationem et cessionem Reverendissimi Domini Stanislai Gomolinsky, Dei gratia episcopi Chelmensis, illius ultimi et immediati possessoris; bez wywodu przodków)

\section{7}

Lipski Jan [arcybiskup (Chełmża - Gniezno)]

kanonik ptocki (recepcja 16 II 1624) prepozyt ptocki (recepcja 16 XI 1635)

${ }^{36}$ Wiśniewski, Katalog prałatów i kanoników sandomierskich, s. 180-181; Szostkiewicz, Katalog biskupów, s. 500; Borkowska, Z dziejów opactwa cystersów w Wąchocku, s. 116-120; Nitecki, Biskupi Kościoła w Polsce, kol. 248-249; Prokop, Sylwetki biskupów tuckich, s. 112-115; Prokop, Wypisy źródłowe do biografii polskich biskupów i opatów, cz. 4, s. 333-334 nr 37; Prokop, Biskupi w gronie prałatów i kanoników, s. 668.

${ }^{37}$ Wiśniewski, Katalog prałatów i kanoników sandomierskich, s. 185; Szostkiewicz, Katalog biskupów, s. 500; Prokop, Poczet biskupów krakowskich, s. 160-163; Nitecki, Biskupi Kościoła w Polsce, kol. 251 (,scholastyk płocki”); Prokop, Sylwetki biskupów tuckich, s. 77-80; Prokop, Wypisy źródłowe do biografii polskich biskupów i opatów, cz. 4, s. 334-335 nr 39; Prokop, Biskupi $w$ gronie prałatów i kanoników, s. 662-663.

${ }^{38}$ Korytkowski, Arcybiskupi gnieźnieńscy, prymasowie i metropolici polscy, t. 3, s. 757nn; Re- 
ADP, ACapPloc 8a, k. 401v-403r (Anno 1624, die Veneris XVI mensis Februarii. Receptio et intronisatio Reverendi Domini Joannis Lipski, cantoris Wladislavienis, Loviciensis, Krusvicensis canonici, regentis cancellariae maioris Sacrae Regiae Maiestatis); tamże, ACapPloc 9, s. 273-275 (Capitulum partiale anno Domini 1635, die decima sexta mensis Novembris. Receptio Reverendissimi Domini Joannis Lipski, nominati Culmensis, referendarii Regni, ad praeposituram Plocensem post ascensum et evectionem in episcopatum Cracoviensem Illustrissimi et Reverendissimi Domini Jacobi Zadzik, episcopi Culmensis et Pomesaniae, supremi Regni cancellarii; podczas recepcji J. Lipski byt reprezentowany przez kantora płockiego Zygmunta Czelgowskiego, jako mandatariusza)

[Testes recognoverunt] patrem Domini Joannis Lipski esse Generosum Laurentium Lipski, iudicem terrae Ravensis, ex armis [pozostawiono puste miejsce na nazwę herbu], matrem vero Generosam Annam Plichcianka ex armis [pozostawiono puste miejsce na nazwę herbu]. Item aviam ex patre Generosam Rębielinska [Rembielińska], aviam ex matre Generosam Olszewska [brak imion oraz nazw herbów].

ADP, ACapPloc 25, s. 326-329 (5 VI 1789: Installatio Perillustris Antoni Luboradzki, parochi Dobrzykoviensis, ad canonicatum cathedralem Plocensem fundi Otolino post fata Perillustris Ignatii Łaczynski, illius ultimi et immedati possessoris, vacantem)

Perillustris Antonius Luboradzki nobilibus, catholicis, legitimis probaeque vitae parentibus, patre videlicet Generoso Joanne Luboradzki, stemmatis Dołęga, matre Antonina Zaborowska, stemmatis Grzymała, avia paterna Marianna Radzyminska, stemmatis Brodziec, avia materna Theresia Podczaska, stemmatis Rolicz, [progenitus est].

ceptiones seu installationes, s. 133; Diecezja chetmińska, s. $42 \mathrm{nr} 31$; Szostkiewicz, Katalog biskupów, s. 500-501; Borkowska, $Z$ dziejów opactwa cystersów w Wachocku, s. 107; Nitecki, Biskupi Kościoła w Polsce, kol. 251-252 (,prepozyt płocki (1630)"); Prokop, Arcybiskupi gnieźnieńscy, s. 208-210; Prokop, Wypisy źródtowe do biografii polskich biskupów i opatów, cz. 4, s. $335 \mathrm{nr}$ 40; Prokop, Biskupi w gronie prałatów i kanoników, s. 667.

${ }^{39}$ Nowowiejski, Płock. Monografia historyczna, s. 82, 211, 303, 351, 355, 643; Nitecki, Biskupi Kościoła w Polsce, kol. 256 („kanonik (1789) i prepozyt płocki oraz pułtuski”); Prokop, Biskupi w gronie prałatów i kanoników, s. 687. 


\title{
Machczyński (Machciński) Teodor [biskup-nominat (Płock)]
}

kanonik plocki (instalacja 5 XI 1706)

kustosz ptocki (instalacja $\left.8[?]^{40} I X 1716\right)^{41}$

\begin{abstract}
ADP, ACapPloc 15, k. 7r-9r (Capitulum partiale sub die Veneris quinta mensis Novembris anno Domini 1706. Installatio Perillustris Theodoris Machcinski, minoris ordinis clerici, ad canonicatum seu praebendam ecclesiae cathedralis Plocensis fundi Ptonsko post obitum olim Perillustris Reverendissimi Domini Valentini Bratoszewski, illius ultimi et immediati possessoris); tamże, ACapPloc 16, k. 19v-20r (Capitulum generale pro festo Nativitatis Beatissimae Virginis Mariae anno Domini 1716. Installatio ad custodiam Perillustris Theodori Machczynski [...] post obitum Perillustris Bartholomaei Tłubicki, custodis Plocensis)
\end{abstract}

Perillustris Theodorus Machcinski nobili genere procreatus [est], videlicet patre Generoso Paulo Machcinski, stemmatis Dołęga, matre vero Generosa Barbara Brochocka, stemmatis Prawdzicz, avia paterna Generosa Elizabeth Samborska, stemmatis Jastrzębiec, avia materna Sophia Romanowna, stemmatis Drogosław, diaecesis et palatinatus huius Plocensis.

\section{Madaliński Bonawentura [biskup (Płock - Włocławek)] kanonik płocki (recepcja 21 II 1653) archidiakon płocki (recepcja 30 VIII 1658) kanclerz płocki (recepcja 28 VII 1661) ${ }^{42}$}

ADP, ACapPloc 9, s. 583-584 (21 II 1653: Receptio Illustris et Admodum Reverendi Domini Bonaventurae Madalinski, minorum ordinum clerici, ad praebendam et canonicatum Plocensem fundi Rypin post assecutionem archidiaconatus Dobrinensis Illustris et Admodum Reverendi Domini Andreae Swinarski, vacantem); tamże, ACapPloc 10, s. 39-40 (30 VIII 1658: Illustris et Admodum Reverendus Dominus Bonaventura Madalinski receptus ad archidiaconatum Plocensem), s. 149-150 (28 VII 1661: Receptio Perillustris et Admodum Reverendi Domini Bonaventurae Madalinski, archidiaconi Plocensis [et] Sremensis, ad cancellariatum in ecclesia catedrali Plocensi post assecutionem alterius dignitatis [nie podano, kogo dotyczy] vacantem)

${ }^{40}$ Brak pewności co do daty dziennej. Por.: Statuty kapituty katedralnej w Ptocku z 1784 roku, s. 58-60 (De sessionibus generalibus capituli).

${ }^{41}$ Nowowiejski, Płock. Monografia historyczna, s. 274, 283, 311, 356; K. R. Prokop, Sakry i sukcesja święceń biskupich pasterzy diecezji płockiej w XVIII wieku, „Studia Płockie” 34 (2006), s. 213-219; Prokop, Biskupi w gronie prałatów i kanoników, s. 679-680.

${ }^{42}$ Korytkowski, Prałaci i kanonicy katedry metropolitalnej gnieźnieńskiej, t. 2, s. 575-577; Receptiones seu installationes, s. 103, 106; Nowowiejski, Płock. Monografia historyczna, s. 67, 371, 375, 381, 383, 563; Szostkiewicz, Katalog biskupów, s. 509; Żebrowski, Zarys dziejów diecezji ptockiej, s. 57 nr 56; Nitecki, Biskupi Kościoła w Polsce, kol. 275; Prokop, Biskupi w gronie prałatów i kanoników, s. 672. 
[Quatuor testes] recognoverunt Illustrem et Admodum Reverendum Bonaventuram Madalinski ortum et propaginem ducere ex nobilibus parentibus, patre videlicet Generoso Petro Madalinski, armorum Larissa, matre vero Anna Chelmska [Chełmska], de armis Ostoia, avia paterna Hedvigi Kobierzycka, de armis Korab, avia materna Zophia Zare[m]bianka, armorum Zaremba.

\section{1}

Mdzewski Michał Maurycy [biskup (Płock)]

kanonik plocki (instalacja 2[?] $]^{43}$ V 1771)

archidiakon dobrzyński (instalacja 4 IX 1779) ${ }^{44}$

ADP, ACapPloc 22, k. 100r-101r (Capitulum generale pro festo S. Sigismundi anno Domini 1771: Installatio Perillustris Michaelis Mdzewski, praepositi curati in Dziatin, ad canonicatum in hac cathedra fundi Radziwie, morte et obitu olim Perillustris canonici Martini Strachocki, illius ultimi et immediati possessoris, vacantem)

Perillustris canonicus Michael Mdzewski nobilibus, catholicis, legitimis probaeque vitae parentibus, patre videlicet Generoso Procopo Mdzewski, stemmatis Dołęga, matre Generosa Theressia de Kądrackie, stemmatis Dołęga, avia paterna Generosa Sophia Kanigowska, stemmatis Lis, avia materna Generosa Barbara Miecznikowska, stemmatis Podkowa, progenitus est.

ADP, ACapPloc 23, s. 432-433 (4 IX 1779: Installatio ad archidiaconiam Dobrinensem); zob. nadto: tamze, ACapPloc 24, s. 79-80 (Laurea doctoralis Perillustris Reverendissimi Michaelis Mdzewski - doktorat obojga praw, nadany M.M. Mdzewskiemu przez Akademię Wileńska 8 III 1781 r.)

Coram Perillustribus Reverendissimis Dominis praelatis et canonicis comparens personaliter Perillustris Reverendissimus Michael Mdzewski, canonicus, ad praelaturam archidiaconatus Dobrinensis in hac cathedra morte et obitu olim Perillustris Simeonis Młocki [...] vacantem, per capitulum praesens electus, principalis, [...] [s. 432] se ad praedictum archidiaconatum Dobrinensem in hac cathedra installari [...] postulavit. Et Perillustres Reverendissimi Domini praelatis et canonici capitulariter congregati [...] eundem Perillustrem archidiaconum ad professionem fidei Catholicae solitumque iuramentum [...] admiserunt.

${ }^{43}$ Brak pewności co do daty dziennej.

${ }^{44}$ Nowowiejski, Ptock. Monografia historyczna, s. 81, 208, 293, 323, 345, 419, 566; Szostkiewicz, Katalog biskupów, s. 513; Żebrowski, Zarys dziejów diecezji płockiej, s. 64 nr 25; Nitecki, Biskupi Kościoła w Polsce, kol. 288; Prokop, Biskupi w gronie prałatów i kanoników, s. 686. 


\title{
32
}

\author{
Mieszkowski Piotr Pawet [biskup (Włocławek)] \\ archidiakon dobrzyński (recepcja 4 V 1663)
}

ADP, ACapPloc 10, s. 225-227 (4 V 1663: Receptio Illustris et Admodum Reverendi Domini Petri Mieszkowski, canonici Vladislaviensis, custodis Crusviciensis, in archidiaconum Dobrinensem in hac ecclesia cathedrali post liberam resignationem Perillustris et Admodum Reverendi Domini Adriani Smiłowski [Śmietowski], canonici Gnesnensis [et] Cracoviensis, illius ultimi et immediati possessoris, vacantem)

Praedictus Illustris et Admodum Reverendus Dominus Petrus Mieszkowski, canonicus Vladislaviensis, progenitus est ex utroque parente nobili, patre videlicet Nobili ac Generoso Bartholomaeo Mieszkowski de armis Odrowąż, palatinatus Calissiensis, districtus Pysdrensis, matre vero Anna Porczynska de armis Ogonczyk, palatinatus Posnaniensis, districtus Kostensis, avia paterna Catharina Piotrowska de armis Porcus alias Swinki, palatinatus Posnaniensis, districtus Kostensis, avia materna Catharina Solecka de armis Gryff, palatinatus Posnaniensis, districtus Kostensis.

Podoski Gabriel Jan [arcybiskup (Gniezno)]

kanonik plocki (instalacja 20 XI 1744) ${ }^{46}$

ADP, ACapPloc 18, s. 174-175 (20 XI 1744: Installatio Perillustris et Reverendissimi Domini Gabrieli Podoski, canonici ecclesiae metropolitanae Gnesnensis, ad canonicatum huius ecclesiae cathedralis Plocensis doctoralem fundi Gocław, post liberam resignationem Perillustris Francisci Podoski, eiusdem canonicatus et fundi ultimi et immediatis possessoris, vacantem; bez wywodu przodków)

${ }^{45}$ Chodyński, Biskupi sufragani włocławscy, s. 64-66 nr 27 („ojcem jego był Bartłomiej, herbu Odrowąż, z powiatu pyzdrskiego województwa kaliskiego, matką Anna Porczyńska, herbu Ogończyk, z województwa poznańskiego”); Receptiones seu installationes, s. 111 („ex patre Bartholomaeo Mieszkowski, de armis Odrowąz, matre Anna Porczynska, de armis Ogonczyk, districtus Costensis, avia paterna Catharina Piotrowska, de armis Swinka, districtus Costensis, avia materna Catharina Sołecka, de armis Gryff, districtus Costensis"); Szostkiewicz, Katalog biskupów, s. 515; Nitecki, Biskupi Kościoła w Polsce, kol. 292; Prokop, Biskupi w gronie prałatów i kanoników, s. 674 .

${ }^{46}$ Korytkowski, Arcybiskupi gnieźnieńscy, prymasowie i metropolici polscy, t. 5, Poznań 1892 , s. 70nn; Szostkiewicz, Katalog biskupów, s. 538; Nitecki, Biskupi Kościoła w Polsce, kol. 354; Prokop, Arcybiskupi gnieźnieńscy, s. 258-261; Prokop, Wypisy źródłowe do biografii polskich biskupów i opatów, cz. 4, s. 344-345 nr 55; Prokop, Biskupi w gronie prałatów i kanoników, s. 683; Przybyszewski, Katalog kanoników krakowskiej kapituły katedralnej, s. 162-163. 
Popławski Mikołaj [arcybiskup (Inflanty/Wenden - Lwów)] dziekan plocki (recepcja 28 I 1678) ${ }^{47}$

ADP, ACapPloc 11, s. 121 (28 I 1678: Receptio Domini decani Poplawski)

In receptione Reverendissimi decani [Nicolai Popławski] testes infrascripti inducti [sunt], primus Nobilis Albertus Rokicki, secundus Generosus Andreas Jasinski, tribunus Sochacoviensis, tertius Nobilis Jacobus Kurdwanowski, quatuor Nobilis Christophorus Boryszewski, qui deposuerunt, Reverendissimum Nicolaum Popławski progenitus esse nobilibus parentibus, patre Nobili Petro Popławski de armis Drzewica, palatinatus Sandomiriensis, districtus Opocnensis, matre Nobili Anna Zwierzchowska de armis Trzaska, palatinatus et districtus Ravensis, avia paterna Nobili Anna Zaiączkowska de armis Drzewica, palatinatus Sandomiriensis, districtus Opocnensis, avia materna Nobili Anna Gorska de armis Rawicz, palatinatus et districtus Ravensis.

\section{5}

Prażmowski Franciszek [biskup (Luck)]

scholastyk plocki (recepcja 2 V 1659) ${ }^{48}$

ADP, ACapPloc 10, s. 57-58 (2 V 1659: Receptio Perillustris et Admodum Reverendi Domini Francisci Prazmowski, minorum ordinis clerici, ad scholasteriam Plocensem post resignationem liberam Illustrissimi et Reverendissimi Domini Nicolai Prazmowski, supremi Regni cancellarii, episcopi Luceoriensis, abbatiae Sieciechoviensis perpetui administratoris, vacantem; bez wywodu przodków)

\section{6}

Prażmowski Mikołaj [arcybiskup (Łuck - Gniezno)]

scholastyk plocki (recepcja 11 VII 1653) ${ }^{49}$

${ }^{47}$ Receptiones seu installationes, s. 113 (,pater eius erat Petrus Popławski, de armis Drzewica, mater Anna Wierzchowska, de armis Trzaska, avia paterna Anna Zajączkowska, de armis Drzewica, avia materna Anna Gorska, de armis Rawicz”); Szostkiewicz, Katalog biskupów, s. 539; Królik, Kapituła kolegiacka w Warszawie, s. 197 nr 179; Nitecki, Biskupi Kościoła w Polsce, kol. 357 („dziekan płocki”); Prokop, Biskupi w gronie prałatów i kanoników, s. 675.

${ }^{48}$ Gacki, Benedyktyński klasztor w Sieciechowie, Radom 1872, s. 194-205; Korytkowski, Prałaci i kanonicy katedry metropolitalnej gnieźnieńskiej, t. 3, Gniezno 1883, s. 279-282; Nitecki, Biskupi Kościoła w Polsce, kol. 359-360 (,scholastyk płocki”); Prokop, Arcybiskupi gnieźnieńscy, s. 221-224; Prokop, Sylwetki biskupów tuckich, s. 106-110; Prokop, Biskupi w gronie prałatów i kanoników, s. 673.

${ }^{49}$ Gacki, Benedyktyński klasztor w Sieciechowie, s. 193-194; Korytkowski, Arcybiskupi gnieź- 
ADP, ACapPloc 9, s. 602-603 (11 VII 1653: Receptio Perillustris et Reverendissimi Domini Nicolai Prażmowski, referendarii Regni, praepositi in ecclesia cathedrali et collegiata S. Michaelis Cracoviensis, archidiaconi Unieioviensis, in scholasticum Plocensem, post resignationem Illustrissimi et Reverendissimi Andreae Trzebicki, vicecancellarii Regni, praepositi Plocensis, vacantem; bez wywodu przodków)

\author{
Rokitnicki Kazimierz [biskup (Ptock)] \\ archidiakon dobrzyński (instalacja 2[?] ${ }^{50}$ V 1738) \\ archidiakon pultuski (instalacja 21 VII 1740) ${ }^{51}$
}

\begin{abstract}
ADP, ACapPloc 17, s. 429, 432-433 (Capitulum generale pro festo S. Sigismundi anno Domini 1738: Aprobatio electionis in archidiaconum Dobrynensem Perillustris ac Reverendissimi Domini Casimiri Rokitnicki. Electio Perillustris et Reverendissimi Domini Casimiri Rokitnicki in archidiaconum Dobrynensem unanimi Perillustrium Dominorum tunc capitulo electionis sub die 18. mensis Aprilis in anno praesenti facta, authoritate praesentis capituli approbatur), s. 433 (j.w.: Installatio Perillustris et Reverendissimi Domini Casimiri Rokitnicki in archidiaconum Dobrynensem post mortem Illustrissimi et Reverendissimi olim Adami Rostkowski, illius ultimi et immediatis possessoris, vacantem; bez wywodu przodków); tamże, ACapPloc 18, s. 3031 (21 VII 1740: Installatio Perillustris et Reverendissimi Domini Casimiri Rokitnicki, archidiaconi Dobrynensis, ad archidiaconatum Pultoviensem post liberam resignationem Perillustris et Reverendissimi Domini Pauli Dromler, illius ultimi et immediati possessoris, vacantem); zob. również: tamże, ACapPloc 20, k. 188 -v (9 IV 1759: Electio Illustrissimi administratoris [sede vacante]); tamże, ACapPloc 22, k. 134v (aprobata testamentu sufragana płockiego K. Rokitnickiego z daty: Warszawa, 30 IV 1772 r.); tamże, ACapPloc 23, s. 356 (Capitulum ex colloquio die 17. mensis Januarii 1779: Fata Illustrissimi suffraganei Casimiri Rokitnicki), j.w. (Capitulum ex colloquio die 18. mensis Januarii 1779: Testamentum Illustrissimi olim suffraganei Rokitnicki)
\end{abstract}

\title{
38
}

Rostkowski Adam [biskup (Luck)] ～kanonik płocki (instalacja 6 III 1693) archidiakon dobrzyński (instalacja 9 VII 1694) ${ }^{52}$

nieńscy, prymasowie i metropolici polscy, t. 4, s. 133nn; Szostkiewicz, Katalog biskupów, s. 540; Nitecki, Biskupi Kościoła w Polsce, kol. 360 („kanonik płocki”); Prokop, Wypisy źródłowe do biografii polskich biskupów i opatów, cz. 4, s. 347-348 nr 59.

${ }^{50 *}$ Brak pewności co do daty dziennej. Por.: Statuty kapituly katedralnej w Plocku z 1784 roku, s. $58-60$.

${ }^{51}$ Nowowiejski, Płock. Monografia historyczna, wg indeksu; Szostkiewicz, Katalog biskupów, s. 546; Żebrowski, Zarys dziejów diecezji płockiej, s. 64 nr 22; Nitecki, Biskupi Kościoła w Polsce, kol. 380; Prokop, Biskupi w gronie prałatów i kanoników, s. 682.

${ }^{52}$ Szostkiewicz, Katalog biskupów, s. 547; Nitecki, Biskupi Kościoła w Polsce, kol. 382 (,,prepozyt pułtuski, archdiakon płocki”); Prokop, Biskupi w gronie prałatów i kanoników, s. 676-677. 
ADP, ACapPloc 13, s. 192-194 (6 III 1693: Installatio Perillustris Admodum Reverendi Domini Adami Rostkowski, Vladislaviensis canonici, ad canonicatum Plocensem fundi Peczek post ascensum Perillustris Reverendissimi Domini Joannis Gomolinski ad dignitatem archidiaconatus Plocensis vacantem), s. 257 (9 VII 1694: Installatio Perillustris et Reverendissimi Domini Adami Rostkowski, praepositi Varsaviensis, ad archidiaconatum Dobrinensem); tamże, ACapPloc 14, k. 4 v (j.w.: Installatio Perillustris Adami Rostkowski ad archidiaconatum Dobrinensem)

[Perillustris Adam Rostkowski installatus est] audita [prius] deductione sub iuramento corporali per testes facta, ex qua constitit primum [eum] parentem esse Nobilem ac Generosum Dominum Joannem Rostkowski de familia Dąmbrowa, matrem vero Nobilem ac Generosam Dominam Annam Sczuczanka de familia Grabie in campo flacio[?], aviam vero paternam Nobilem ac Generosam Dominam Catharinam Brolinska[?] de familia Prus, insuper aviam maternam Nobilem ac Generosam Dominam Caeciliam Popowska de stemmate Kolumna.

Starczewski Stanisław [biskup (Płock)]

kanonik plocki (recepcja 21 II 1614) $)^{53}$

ADP, ACapPloc 8a, k. 197r-v (21 II 1614: Receptio ad canonicatum et praebendam ecclesiae cathedralis Plocensis fundi Radziwie Reverendi Domini Stanislai Starczewski; bez wywodu przodków)

\section{0}

Szembek Onufry Kajetan [biskup (Płock)]

dziekan plocki (instalacja 9 IX 1790) $)^{54}$

ADP, ACapPloc 25, s. 523-528 (9 IX 1790: Installatio ad decanatum cathedralem Plocensem Illustrissimi Onuphrii Szembek, cathedralis Cracoviensis primicerii, collegiatae regiae Varsa-

${ }^{53}$ Nowowiejski, Ptock. Monografia historyczna, wg indeksu; Szostkiewicz, Katalog biskupów, s. 559; Żebrowski, Zarys dziejów diecezji płockiej, s. 63 nr 14; Nitecki, Biskupi Kościoła w Polsce, kol. 416; Prokop, Biskupi w gronie prałatów i kanoników, s. 666.

${ }^{54}$ Receptiones seu installationes, s. 154 („,educta nobilitate ex patre Paulo de Słupow Szembek, exercituum Regni colonello, armorum Szembek, matre Hedvigi de Łuczyckie, de armis Nowina, matre patris Barbara Bethacka [sic!], de armis Topor, matre matris Theressia Scudzimirowna [sic!], de armis Ostoia"); A. Mańkowski, Prałaci i kanonicy katedralni chetmińscy od założenia kapituty do naszych czasów, Torun 1928 [osobne odbicie z „Roczników Towarzystwa Naukowego w Toruniu"], s. 210; Nowowiejski, Ptock. Monografia historyczna, s. 72, 618, 636; Szostkiewicz, Katalog biskupów, s. 565; Żebrowski, Zarys dziejów diecezji płockiej, s. $58 \mathrm{nr}$ 66; Królik, Kapituła kolegiacka w Warszawie, s. 200 nr 222; Nitecki, Biskupi Kościoła w Polsce, kol. 431; Prokop, Wypisy źródlowe do biografii polskich biskupów i opatów, cz. 4, s. 358-359 nr 81; Prokop, Biskupi w gronie prałatów i kanoników, s. 687-688; Przybyszewski, Katalog kanoników krakowskiej kapituły katedralnej, s. 221. 
viensis archidiaconi, abbatis coadiutoris Praemetensis, morte et obitu olim Perillustris Reverendissimi Adalberti Mokronowski, illius ultimi et immediati possessoris, vacantem), s. 531-533 (Eductio nobilitatis Illustrissimi Onuphrii Szembek); zob. nadto: tamże, ACapPloc 22, $k$. 205r-206r (Capitulum generale pro festo S. Sigismundi anno Domini 1774 - dotyczy instalacji na koadiutora przy prepozycie płockim, biskupie Krzysztofie Hilarym Szembeku, Marcina Szeptyckiego)

Illustrissimus decanus [Onuphrius Szembek] produxit quatuor stemmata dignissimae domus suae, 1 mum Szembekorum paternum Kozy vocitatum, $2^{\text {ndum }}$ maternum Łuczycciorum [ $\lfloor u c z y c k a]$ Nowina dictum, 3 tium Bełhacciorum [Bełchacka] aviae ex patre Topor dictum, $4^{\text {tum }}$ aviae ex matre Sendzimiriorum [Sendzimirówna] Ostoja nuncupatum.

\section{1}

Szyszkowski Mikołaj [biskup (Warmia)] ～kanonik płocki (recepcja 15 IV 1611) kanclerz ptocki (recepcja 27 I 1612) canonicus natus [opat czerwiński] (recepcja 21 I 1622) ${ }^{55}$

ADP, ACapPloc 8a, k. 136v-138r (15 IV 1611: Receptio ad canonicatum et praebendam fundi Radziwie Admodum Reverendi Domini Nicolai Szyskowski, praepositi Poltoviensis); tamże, $k$. 160r-161v (27 I 1612: Receptio Admodum Reverendi Domini Nicolai Szyskowski in dignitatem cancellariae Plocensis)

Statuit, qui medio corporali iuramentum principalem emanatum esse nobilem ex nobilique prosapia progenitum recognoverunt ac stemmati eiusdem huiusmodi esse cognoverunt, patris quidem cuius nomen Joannes Szyskowski, esse stemma Ostoia, matris vero Anna Uieyska, [stemma esse] Jastrzembiecz, avia patris ipsiusmet Annae Skarszewska, esse Lesczycz alias Brog, aviae vero matris, olim Annae Uieyska, Dorothea Jaroczka, stemma esse Panna na Niedzwiedziu [na marginesie dopisane inną ręką: Rawicz].

ADP, ACapPloc 8a, k. 366r-367r (21 I 1622: Reverendissimi in Christo Patris Domini, Domini Nicolai Syskowski, abbatis Cervenensis, canonici nati Plocensis, receptio)

Anno Domini millesimo sexcentesimo vigesimo secundo, die Veneris XXI. Januarii [...], coram Admodum Reverendis Dominis [praelatis et canonicis] comparavit Venerabilis Dominus Albertus Targovius, parochus in Przewodowo, legitimus plenipotens et mandatarius Reverendissimi Domini Nicolai Syskowski, Divina pacientia abbatis Cervenensis, canonici nati Plocensis [...], et habens suis manibus

${ }^{55}$ Szostkiewicz, Katalog biskupów, s. 566; Folwarski, Poczet opatów klasztoru kanoników regularnych w Czerwińsku, s. 29-31; Stownik biograficzny kapituły warmińskiej, oprac. zbior., s. 250 (A. Kopiczko); Nitecki, Biskupi Kościoła w Polsce, kol. 436 („kanonik płocki i opat komendatoryjny czerwiński"); Prokop, Wypisy źródłowe do biografi polskich biskupów i opatów, cz. 4, s. $361 \mathrm{nr}$ 84; Prokop, Biskupi w gronie prałatów i kanoników, s. 665. 
literas investiturae seu institutionis praenominati Domini Syskowski in abbatiam Cervenensem et canonicatum Plocensem atque scholasteriae collegiatae [Sancti Michaelis] Plocensis, de actu et data Poltoviae, die tertia mensis Augusti anno Domini MDCXXXI, manu Illustrissimi et Reverendissimi Domini, Domini Henrici Firley de Dąmbrowica, Dei et Apostolicae Sedis gratia episcopi Plocensis subscriptus [...], postulavit [...] [k. 367r] supranominatum Dominum Nicolaum Syskowski, abbatem Cervenensem, in canonicum natum Plocensem [...] recipi, stallum in choro, locum et vocem in capitulo, cum plenitudine iuris canonici assignari [...]. Et Admodum Reverendi Domini praenominati [...] supranominatum Reverendissimum Dominum Nicolaum Syskowski etc. in persona plenipotentis praedicti $[. .$.$] in canonicum natum Plocensem et fratrem receperunt stallumque in$ choro, locum et vocem in capitulo [...] dederunt et assignarunt.

\section{2}

Tolibowski Ludwik biskup (Płock)

kustosz plocki (instalacja 5 I 1657)

ADP, ACapPloc 10, s. 7 (5 I 1657: Intromissio Illustris et Admodum Reverendi Domini Ludovici Tholibowski ad custodiam Plocensem; bez wywodu przodków)

Tolibowski Wojciech biskup (Płock) [(- Poznań)]

kanonik plocki (recepcja 13 I 1645) ${ }^{57}$

ADP, ACapPloc 9, s. 52-58 (13 I 1645: Receptio Perillustris et Reverendissimi Domini Alberti Tholibowski, suffraganei et praepositi Sanctae Mariae Magdalenae, in canonicum fundi Strozewko)

Constitutus personaliter Perillustris et Reverendissimus Dominus Albertus Tholibowski, suffraganeus et praepositus Sanctae Mariae Magdalenae Plocensis Ordinis Praemonstratensis [...], petiit se in canonicum fundi Strożewko post mortem Admodum Reverendi Domini olim Lucae Makowski, illius ultimi et immediati possessoris, recepi et instalari. Et Admodum Reverendi Domini capitulum [...]

${ }^{56}$ Receptiones seu installationes, s. 104 (,,probata nobilitate ex patre Generoso Martino Tholibowski, succamerario Brestensi, de armis Nałęcz, matre Anna de Zbelcice Grodzinska, de armis Paprzyca, matre patris Anna Chełmicka de armis Nałencz, matre matris Hedvigi Rudnicka de armis Lis”); Szostkiewicz, Katalog biskupów, s. 571; Żebrowski, Zarys dziejów diecezji płockiej, s. $64 \mathrm{nr}$ 18; Nitecki, Biskupi Kościoła w Polsce, kol. 448-449; Prokop, Biskupi w gronie prałatów i kanoników, s. 672-673.

${ }^{57}$ Receptiones seu installationes, s. 103; Nowowiejski, Ptock. Monografia historyczna, wg indeksu; Szostkiewicz, Katalog biskupów, s. 571; J. Nowacki, Dzieje archidiecezji poznańskiej, t. 2, s. 107; Żebrowski, Zarys dziejów diecezji płockiej, s. 63-64 nr 15; Nitecki, Biskupi Kościoła w Polsce, kol. 449 (,proboszcz w Płocku”); Prokop, Biskupi w gronie prałatów i kanoników, s. 670. 
eundem principalem institutum in canoniam et confratrem recipiendum esse consenserunt. [...] [s. 53] [...] Supranominatus Perillustris et Reverendissimus Dominus Albertus Tholibowski, episcopus Lacedaemoniensis, suffraganeus et praepositus Plocensis, ad probandam et deducendam generis nobilitatem ac declaranda quatuor stemmata statuit testes omni meliori modo maiores [...], qui medio iuramento corporali recognoverunt Reverendissimum Dominum Albertum Tholibowski illustribus ac generosis parentibus esse procreatum, patre scilicet Andrea Tholibowski, capitaneo Bobroviensi, filio olim Alberti Tholibowski, dapiferi Brestensis, armorum Nałencz, matre vero Anna Chełmicka, olim Adriani Chełmicki, dapiferi Brestensis, filia, itidem armorum Nałencz, avia paterna Agnete Piwowna, pocillatoris Costinensis filia, armorum Prawdzic, avia materna [brak imienia] de Koneczko Grabska, castellani Crusficiensis [sic!] filia, stemmatis Pomian.

Trzebicki Andrzej [biskup (Przemyśl - Kraków)]

kanonik płocki (recepcja 27 IV 1633)

scholastyk płocki (recepcja 14 I 1637) prepozyt płocki (recepcja 11 VII 1653)

\begin{abstract}
ADP, ACapPloc 8b, s. 159-161 (Receptio Domini Andreae Trzebicki ad canonicatum et praebendam in ecclesia cathedrali Plocensi fundi Kaczorowo post mortem et obitum illius ultimi possessoris Reverendi olim Joannis Garwaski vacantem, anno [1633] die Mercurii vigesima septima mensis Aprilis); tamże, s. 324-327 (Anno Domini millesimo sexcentesimo trigesimo septimo, die Mercurii decima quarta mensis Januarii. Receptio Reverendi Domini Andreae Trzebicki ad scholasteriam cathedralem Plocensem, ex reservatione Sanctissimi [Domini nostri] et ob non dimissionem per Illustrem et Admodum Reverendum Tobiam Małachowski, abbatem Paradisiensem, in certo tempore tunc expresso et alapso, eius ultimum et immediatum possessorem, vacantem, provisi); tamże, ACapPloc 9, s. 601-602 (11 VII 1653: Actus receptionis Reverendissimi Domini Andreae Trzebicki, vicecancellarii Regni, cantoris Gnesnensis, Cracoviensis canonici, ad praeposituram Plocensem)
\end{abstract}

Dictus plenipotens [podczas aktu recepcji A. Trzebicki byt reprezentowany przez plenipotenta w osobie notariusza konsystorza płockiego Jakuba Slaskiego] testibus quatuor omni exceptione maioribus nobilibus, videlicet Andreae Starczewski, Stanislao Libicki, Alberto Zglenicki [et] [brak imienia] Dąmbrowski examinatis et iuratis, deduxit principalem suum Nobili Martino Trzebicki, stemmatis Łabęcz, parente, matre vero Catherina Rozmiatowska, stemmatis Mucro inter duas lunelas,

${ }^{58}$ Korytkowski, Prałaci i kanonicy katedry metropolitalnej gnieźnieńskiej, t. 4, Gniezno 1883, s. 127-138; Nowowiejski, Płock. Monografia historyczna, s. 62, 64, 126, 354; Szostkiewicz, Katalog biskupów, s. 574; A. Przyboś, M. Rożek, Biskup krakowski Andrzej Trzebicki. Z dziejów kultury politycznej i artystycznej w XVII stuleciu, Warszawa - Kraków 1989, s. 15, 21; Prokop, Poczet biskupów krakowskich, s. 173-177; Nitecki, Biskupi Kościoła w Polsce, kol. 454 („,kanonik płocki (1633), prepozyt płocki”); Prokop, Wypisy źródłowe do biografii polskich biskupów i opatów, cz. 4, s. 363-364 nr 88; Prokop, Biskupi w gronie prałatów i kanoników, s. 667-668. 
avia paterna Anna Kałowska ex armis Tres hastas, avia materna Nobili Anna Domanska pro stemmate Agnum cum certis signis deferente, ortum suum ducere.

\section{5}

Ujejski Tomasz [biskup (Kijów)] kanonik płocki (instalacja 13 XII 1647) ${ }^{59}$ ADP, ACapPloc 9, s. 259-261 (13 XII 1647: Installatio Illustris et Admodum Reverendi Domini Thomae de Rupniow Vieyski, canonici [Plocensis] fundi Pęczek)

Venientes ad locum capitularem nobiles ac generosi domini [testes] [] recognoverunt Illustrem et Admodum Reverendum Dominum Thomam Vieyski, canonicum, nobilibus ac generosis parentibus esse progenitum, patre videlicet Stanislao de Rupniow Vieyski, armorum Srzeniawa, matre vero Susanna de Wrocimowice Paczkowna, armorum Orlica, avia paterna Margaretha Efforinowna, armorum Gniazdo, avia materna Hedvigi Sze[m]bekowna, armorum Szembek.

\section{6}

Wessel Adam Augustyn [biskup (Inflanty/Wenden - Kamieniec)]
kanonik ptocki (instalacja 22 VI 1708) ${ }^{60}$

ADP, ACapPloc 15, k. 21r (22 VI 1708: Installatus est Perillustris et Reverendissimus Dominus Augustinus Weßel, Romanus [sic!], ad canonicatum cathedralem Plocensem post obitum et fata Perillustris olim et Reverendissimi Joannis Komeski, canonici Plocensis, illius ultimi et immediati possessoris, vacantem; bez wywodu przodków)

47

Wężyk Walenty [biskup (Chełm/Krasnystaw - Przemyśl)]

kanonik ptocki (instalacja 2[?] $\left.{ }^{61} V 1740\right)^{62}$

${ }^{59}$ Korytkowski, Prałaci i kanonicy katedry metropolitalnej gnieźnieńskiej, t. 4, s. 184-195; Nowowiejski, Plock. Monografia historyczna, s. 544, 553-554; Szostkiewicz, Katalog biskupów, s. 577; Encyklopedia wiedzy o jezuitach, s. 709; Stownik biograficzny kapituty warmińskiej, s. 262-263 (A. Kopiczko); Nitecki, Biskupi Kościoła w Polsce, kol. 462 („kanonik płocki (1647)”); Prokop, Biskupi kijowscy, s. 83-89; I. Makarczyk, Tomasz Ujejski (1612-1689) - biskup kijowski, prepozyt warmiński, jezuita, Olsztyn 2005, s. 24-27; Prokop, Biskupi w gronie prałatów i kanoników, s. 670-671.

${ }^{60}$ W. Bukowski, Katalog opatów jędrzejowskich. Próba ustalenia chronologii, [w:] Cystersi $w$ Polsce. W 850-lecie fundacji opactwa jędrzejowskiego, pod red. D. Olszewskiego, Kielce 1990, s. 203; Nitecki, Biskupi Kościoła w Polsce, kol. 474; Prokop, Biskupi kamienieccy, s. 269-278.

${ }^{61 *}$ Brak pewności co do daty dziennej.

${ }^{62}$ Korytkowski, Prałaci i kanonicy katedry metropolitalnej gnieźnieńskiej, t. 4, s. 275-279; Sarna, Biskupi przemyscy, cz. 2, s. 466-470; Szostkiewicz, Katalog biskupów, s. 582; Nitecki, Biskupi Kościoła w Polsce, kol. 475-476 (,kanonik płocki”); Prokop, Wypisy źródłowe do biografii polskich 
ADP, ACapPloc 18, s. 25-27 (Capitulum generale pro festo S. Sigismundi anno Domini 1740: Installatio Perillustris Valentini Węzyk ad canonicatum fundi Gniazdowo in ecclesia cathedrali Plocensi post liberam resignationem Perillustris Antonii Wolski, illius canonicatus et praebendae ultimi et immediati possessoris, vacantem)

Perillustris Dominus Valentinus Węzyk, canonicus, nobilibus, legitimis probaeque vitae parentibus, patre videlicet Laurentio de Osiny Węzyk, stemmatis Węzyk, matre G[enerosa] Marianna Olszowska, stemmatis Prus, avia paterna G[enerosa] Marianna Bojanowska, stemmatis Junosza, avia materna G[enerosa] Catharina de Kurozwęki Męcinska, stemmatis Poraj, progenitus est.

\section{8}

Wierzbowski Stefan [biskup (Warmia)] dziekan płocki (instalacja 14 I 1707) ${ }^{63}$

ADP, ACapPloc 15, k. 10v-12r (14 I 1707: Installatio ad praelaturam decaniae ecclesiae cathedralis Plocensis post liberam resignationem Illustrissimi et Reverendissimi Domini Nicolai Popławski, episcopi Livoniae, Perillustris et Reverendissimi Domini Stephani Wierzbowski, Gnesnensis [et] Varsaviensis cantori praelati, cathedralis Posnanienis ecclesiarum canonici, vicarii in spiritualibus et officialis Varsaviensis ac per Ducatum Mazoviae generalis; bez wywodu przodków)

Wolicki Cyprian Kazimierz [biskup (Włocławek [Gdańsk])]

koadiutor-kanonik płocki (instalacja 5 II 1751) ${ }^{64}$

ADP, ACapPloc 19, k. 44r-45r (5 II 1751: Installatio ad coadiutoriam cum futura successione canonicatus ecclesiae cathedralis Plocensis fundi Goctaw, possessionis vero Perillustris Caroli Kreni, Perillustris Domini Cypriani Wolicki, canonici collegiatae Pultoviensis; bez wywodu przodków)

biskupów i opatów, cz. 4, s. 368 nr 95; Prokop, Biskupi w gronie prałatów i kanoników, s. 682; Przybyszewski, Katalog kanoników krakowskiej kapituły katedralnej, s. 236.

${ }^{63}$ Korytkowski, Prałaci i kanonicy katedry metropolitalnej gnieźnieńskiej, t. 4, s. 287-289 („,syn Władysława z Wielkiego Chrząstowa Wierzbowskiego, stolnika dobrzyńskiego, z województwa i obwodu [sic!] łęczyckiego, herbu Jastrzębiec, i Ewy z Ossowa Ossowskiego, z województwa pomorskiego, obwodu [sic!] starogrodzkiego, herbu Prus; miał babkę po ojcu Zofię z Bronna i Paradyża Broniszównę, herbu Wieniawa, po matce Zofię z Chruścina Chruścińską, herbu Jastrzębiec”); Receptiones seu installationes, s. 129 (,cuius pater erat Chrisostomus Wierzbowski, ex palatinatu Lanciciensi, de armis Jastrzębiec, mater Barbara Sokołowska, de armis Slepowron, mater patris Marianna Kossowska, de armis Dołęga, mater matris Hedvigis Oporowska, de armis Trzy Kroie"); Nowowiejski, Plock. Monografia historyczna, s. 459, 644; Szostkiewicz, Katalog biskupów, s. 582--583; Królik, Kapituła kolegiacka w Warszawie, s. 202 nr 247; Nitecki, Biskupi Kościoła w Polsce, kol. 478 („,dziekan płocki”).

${ }^{64}$ Chodyński, Biskupi sufragani włoctawscy, s. 86-88; Szostkiewicz, Katalog biskupów, s. 588; Nitecki, Biskupi Kościoła w Polsce, kol. 491 („,kanonik pułtuski i płocki (1764)”); Prokop, Biskupi w gronie prałatów i kanoników, s. 684. 
Wołlowicz Andrzej [biskup (Włocławek)] kanonik plocki (instalacja 8[?] $]^{65}$ IX 1773) ${ }^{66}$

ADP, ACapPloc 22, k. 188v-189r (Capitulum generale pro festo Nativitatis Beatissimae Virginis Mariae anno Domini 1773: Installatio Perillustris Reverendissimi Domini Andrae Woltowicz ad canonicatum in hac cathedra fundi Radziwie, morte et obitu olim Perillustri canonici Starorypinski, illius ultimi et immediati possessoris, vacantem); tamże, ACapPloc 23, s. 484 (3 V 1780: Iuramentum Perillustris canonici Woltowicz circa primum ingressum sui ad stubam capitularem), 492 (j.w.: Habilitatio Perillustris Wollowicz), 518-519 (14 VII 1780: Deductio nobilitatis Perillustris canonici Andreae Wołtowicz; w kapitule płockiej instalowany na kanonikat przez petnomocnika $w$ roku 1773)

Perillustris Andreas Wołowicz, canonicus, nobilibus, legitimis, probae vitae parentibus, patre videlicet Stanislao, subdapifero Łukoviensi, olim Feliciani Wołowicz, capitanei Przyłuscensis, filio, stemmatis Bogoria, matre Magnifica Antonina Wołowiczowa, Ameliae de Zenowice filia, Magnifici Stanislai consortis, stemmatis Bogoria, avia paterna Magnifica Catharina Vladislai et Elisabethae Rogolinskie filia, Feliciani Wołowicz consorte, Magnifici Stanislai mater, stemmatis Rawicz, avia materna Magnifica Emilia Christophori et Hedvigis Zienowiec [Zienowicz] de Zenowicze, Magnifici palatini Minscensis filia, Alexandri Wołowicz consors, stemmatis Zienowiecz, [oriundus est].

Wyhowski (Wychowski) Aleksander [biskup (Łuck)] kanonik płocki (recepcja/instalacja 9 IX 1687) ${ }^{67}$

ADP, ACapPloc 12, b.p. (9 IX 1687: Receptio Perillustris Alexandri Wyhowski, cantoris Kiioviensis, ad canonicatum fundi Drobnica); tamże, ACapPloc 13, s. 18-20 (j.w.: Installatio Perillustris Alexandri Wychowski, cantoris Kiioviensis, in canonicum fundi Drobnica)

Suprascriptus Perillustris et Admodum Reverendus Dominus Alexander Wyhowski progenitus est nobilibus parentibus, patre scilicet Generoso Constantino Wyhowski, pincerna Culmensi, stemmatis Orzeł biały w czerwonym polu, w nim Habdank na piersiach, palatinatus Podoliae, matre vero Regina Mesczerinowna ex

${ }^{65^{*}}$ Brak pewności co do daty dziennej.

${ }^{66}$ Królik, Kapituła kolegiacka w Warszawie, s. 202 nr 256; Włocławek. Dzieje miasta, t. 1 - Od początków do 1918 roku, pod red. J. Staszewskiego, Włocławek 1999, s. 569-570; Nitecki, Biskupi Kościoła w Polsce, kol. 493 („,kanonik płocki (1773) i opat komendatoryjny czerwiński”); Prokop, Biskupi w gronie prałatów i kanoników, s. 686.

${ }^{67}$ Gacki, Benedyktyński klasztor w Sieciechowie, s. 207-208; Szostkiewicz, Katalog biskupów, s. 590; Nitecki, Biskupi Kościoła w Polsce, kol. 498; Prokop, Sylwetki biskupów tuckich, s. 128-131; Prokop, Biskupi w gronie prałatów i kanoników, s. 676. 
Ducatu Lituaniae, stemmatis Pogonia, avia paterna Helena Łaskowna, stemmatis Habdank obrócony na dół z Krzyżem, avia materna Tacyana Połubienska, stemmatis Łabędź za kratą.

\section{2}

Zadzik Jakub [biskup (Chełmża - Kraków)]

kanonik plocki (recepcja 2 V 1614) ${ }^{68}$

ADP, ACapPloc 8a, k. 201v-202v (2 V 1614: Actus receptionis ad canonicatum et praebendam ecclesiae cathedralis Plocensis fundi Sządzino Illustris et Admodum Reverendi Domini Jacobi Zadzik, iuris utiriusque doctoris, praepositi Vladislaviensis, secretarii Regni maioris; bez wywodu przodków)

Zajerski Franciszek [biskup (Euck)] Kanonik płocki (recepcja 17 V 1614) ${ }^{69}$

ADP, ACapPloc 8a, k. 205r (17 V 1614: Receptio Admodum Reverendi Francisci Zaierski ad canonicatum Plocensem fundi Goczław; bez wywodu przodków)

\section{4}

Zatuski Andrzej Chryzostom biskup (Kijów) [(- Płock - Warmia)]
prepozyt płocki (instalacja 27 XI 1691, powtórnie 19 IV 1709) ${ }^{70}$

ADP, ACapPloc 12, b.p. (27 X 1691: Installatio Illustrissimi et Reverendissimi Domini Andreae

${ }^{68}$ Korytkowski, Prałaci i kanonicy katedry metropolitalnej gnieźnieńskiej, t. 4, s. 383-399; Receptiones seu installationes, s. 85; Wiśniewski, Katalog prałatów i kanoników sandomierskich, s. 318; Diecezja chetmińska, s. 42 nr 30; Nowowiejski, Ptock. Monografia historyczna, s. 354; Szostkiewicz, Katalog biskupów, s. 591-592; Królik, Kapituła kolegiacka w Warszawie, s. $203 \mathrm{nr}$ 263; Prokop, Poczet biskupów krakowskich, s. 166-169; J. Dorobisz, Jakub Zadzik (1582-1642), Opole 2000, s. 65-66; Nitecki, Biskupi Kościoła w Polsce, kol. 504; Prokop, Wypisy źródtowe do biografii polskich biskupów i opatów, cz. 4, s. $373 \mathrm{nr}$ 104; Prokop, Biskupi w gronie prałatów i kanoników, s. 666.

${ }^{69}$ Szostkiewicz, Katalog biskupów, s. 592; Nitecki, Biskupi Kościoła w Polsce, kol. 504 („,kanonik płocki, dziekan pułtuski”); Prokop, Biskupi w gronie prałatów i kanoników, s. 667.

${ }^{70}$ Korytkowski, Prałaci i kanonicy katedry metropolitalnej gnieźnieńskiej, t. 4, s. 405-430; Receptiones seu installationes, s. 112; Nowowiejski, Ptock. Monografia historyczna, wg indeksu; Szostkiewicz, Katalog biskupów, s. 592; W. Góralski, Andrzej Chryzostom Załuski, biskup płocki (1692-1698). Wkład w dzieło recepcji reformy trydenckiej, Warszawa 1987, s. 19; Stownik biograficzny kapituly warmińskiej, oprac. zbior., Olsztyn 1996, s. 289-290 (A. Kopiczko); Nitecki, Biskupi Kościoła w Polsce, kol. 505 („kanonik pułtuski”); Prokop, Wypisy źródłowe do biografii polskich biskupów i opatów, cz. 4, s. 373-374 nr 105; Prokop, Biskupi w gronie prałatów i kanoników, s. 676. 
Zaluski, episcopi Kiioviensis, ad praeposituram cathedralem Plocensem morte et obitu Illustrissimi et Reverendissimi Domini Boguslai Lesczynski, episcopi Luceoriensis, praepositi Plocensis); tamże, ACapPloc 13, s. 113-114 (j.w.: Installatio Illustrissimi Domini episcopi Chioviensis ad praeposituram cathedralem Plocensem)

ADP, ACapPloc 15, k. 25r-v (19 IV 1709)

Coram Perillustribus et Reverendissimis praelatis et canonicis, capitulariter congregatis, constitutus personaliter Admodum Reverendus Stanislaus Rychlicki, decanus Raciązensis, praepositus Drobinensis ad Sanctam Praxedem, uti et tanquam Celsissimi principis Illustrissimi et Reverendissimi Andreae Christostomi in Załuskie Załuski, episcopi Varmiensis et Sambiensis, provisi et instituti ad praeposituram ecclesiae cathedralis Plocensis, unus ex aliis plenipotentiarius et procurator $[\ldots]$ ad actum installationis [...], petiit se nomine principalis sui iuxta morem huius capituli et consuetudine intallari, ad possessionem admitti, stallum in choro, locum et vocem in capitulo cum plenitudine iuris canonici dari et assignari. Et Perillustres et Reverendissimi Domini praelati et canonici [...] [k. 25v] ipsum installari et ad realem dictae praepositurae admitti, stallum in choro, locum et vocem in capitulo cum plenitudine iuris canonici dari et assignari decreverunt.

\section{5}

Załuski Andrzej Stanisław [biskup (Płock - Łuck - Chełmża - Kraków)] koadiutor-prepozyt płocki (instalacja 30 I 1711) ${ }^{71}$

ADP, ACapPloc 15, k. 43r-v (30 I 1711: Installatio Perillustris et Reverendissimi Domini Andreae comitis in Zaluskie Zaluski, canonici Cracoviensis, decani Pultoviensis, ad praeposituram et praelaturam in ecclesia cathedrali Plocensi iure coadiutoriae; bez wywodu przodków)

Załuski Józef Andrzej [biskup (Kijów)] archidiakon plocki (instalacja 2[?] $]^{72}$ V 1719) ${ }^{73}$

ADP, ACapPloc 16, k. 36v-38r (Capitulum generale pro festo Sancti Sigismundi 1719 r.: Instal-

${ }^{71}$ Nowowiejski, Ptock. Monografia historyczna, wg indeksu; Szostkiewicz, Katalog biskupów, s. 592-593; Nitecki, Biskupi Kościoła w Polsce, kol. 506 („,dziekan pułtuski, prepozyt płocki”); Prokop, Wypisy źródłowe do biografii polskich biskupów i opatów, cz. 4, s. 374 nr 106; Prokop, Biskupi w gronie prałatów i kanoników, s. 678; Przybyszewski, Katalog kanoników krakowskiej kapituty katedralnej, s. 247-248.

${ }^{72 *}$ Brak pewności co do daty dziennej.

${ }^{73}$ Szostkiewicz, Katalog biskupów, s. 593; Królik, Kapituła kolegiacka w Warszawie, s. $203 \mathrm{nr}$ 264; Nitecki, Biskupi Kościoła w Polsce, kol. 506; Prokop, Wypisy źródłowe do biografii polskich biskupów i opatów, cz. 4, s. 374-375 nr 107; Prokop, Biskupi w gronie prałatów i kanoników, s. 679; Przybyszewski, Katalog kanoników krakowskiej kapituly katedralnej, s. 248-249. 
latio Perillustris et Reverendissimi Domini Josephi Zatuski, minoris ordinis clerici, ad archidiaconatum Plocensem, post mortem olim Illustrissimi et Reverendissimi Domini Pauli Antonii Zaluski, suffraganei Plocensis, archidiaconi Pultoviensis, illius ultimi et immediati possessoris, vacantem; bez wywodu przodków)

Załuski Ludwik Bartłomiej biskup (Przemyśl) [(- Płock)] scholastyk plocki (instalacja 13 VIII 1694) ${ }^{74}$

ADP, ACapPloc 13, s. 258 (13 VIII 1694: Installatio Illustrissimi et Reverendissimi Domini Ludovici Zatuski, Dei et Apostolicae Sedis gratia episcopis Alexiensis, suffraganei Praemisliensis, ad scholasteriam Plocensem)

Illustrissimus et Reverendissimus Dominus suffraganeus Praemisliensis ortus est ex patre Illustrissimo Alexandro Załuski, palatino Ravensi, de stemmate Junosza, et Illustrissima Catharina Olszewska, de stemmate Prus, et Magnifica [brak imienia] Duninowna, avia matris suae, de stemmatis Łabędź, et Magnifica [brak imienia] Oborska, avia de patre, stemmatis Columnae.

ADP, ACapPloc 14, s. 4v-5r (13 VIII 1694: Installatio Perillustris et Reverendissimi Domini Ludovici Zatuski, Dei et Apostolicae Sedis gratia episcopi Alexiensis, suffraganei Praemisliensis, ad scholasteriam Plocensem)

Testes idoneos [...] sub iuramento deduxerunt Perillustrem et Reverendissimum suffraganeum [Praemisliensem] esse ex patre Illustrissimo Alexandro Załuski, palatino Ravensi, de stemmate Junosza, et Illustrissima [pozostawiono miejsce na wpisanie imienia] Olszowska de stemmate Prus, et Magnifica [pozostawiono miejsce na wpisanie imienia] Duninowna, avia matris suae, de stemmate Łabedz, et Magnifica Domina [pozostawiono miejsce na wpisanie imienia] Oborska, avia de patre, stemmatis Columnae.

58

Załuski Marcin (starszy) [biskup (Ptock)]

kanonik płocki (instalacja 16 III 1696) scholastyk płocki (instalacja 18 X 1697) ${ }^{75}$

${ }^{74}$ Szostkiewicz, Katalog biskupów, s. 593; Nitecki, Biskupi Kościoła w Polsce, kol. 506-507; Prokop, Biskupi w gronie prałatów i kanoników, s. 677; Przybyszewski, Katalog kanoników krakowskiej kapituly katedralnej, s. 250.

${ }^{75}$ Nowowiejski, Płock. Monografia historyczna, s. 80; Szostkiewicz, Katalog biskupów, s. 593594; Nitecki, Biskupi Kościoła w Polsce, kol. 507 („kanonik i prepozyt płocki”); Prokop, Biskupi w gronie prałatów i kanoników, s. 677-678. 
ADP, ACapPloc 13, s. 290-291 (16 III 1696: Installatio Perillustris Domini Martini Załuski, canonici Cracoviensis, decani Pultoviensis, ad canonicatum fundi Kania post mortem et obitum Perillustris et Admodum Reverendi Domini Alexandri Podkański, Chetmensis [et] Chioviensis decani, custodis Jarostaviensis, cantoris Otycensis), s. 315-316 (18 X 1697: Installatio ad scholasteriam in ecclesia cathedrali Plocensi Illustrissimi et Reverendissimi Domini Martini Załuski, Dei et Apostolicae Sedis gratia episcopi Rosmensis, suffraganei Plocensis)

Perillustris et Reverendissimus Dominus Martinus Załuski progenitus [est] nobilibus parentibus ac praedecessoribus clarissimis, scilicet patre Illustri Alexandro Załuski, palatino Ravensi, stemmatis Junosza, et Illustri [brak imienia] Olszewska, matre, stemmatis Prus, avia paterna Illustri [brak imienia] Oborska, stemmatis Columnae, avia materna Illustri [brak imienia] Duninowna, stemmatis Łabędź.

\section{9}

Zatuski Marcin (młodszy) [biskup (Ptock)]

scholastyk ptocki (instalacja 28 IX 1714)

dziekan plocki (instalacja 23 XI 1725)

koadiutor-prepozyt ptocki (instalacja 11 VII 1749) ${ }^{76}$

ADP, ACapPloc 15, k. 76r-77r (28 IX 1714: Installatio Perillustris et Reverendissimi Domini Martini Zatuski, scholastici instituti Plocensis, ad praelaturam scholasteriae ecclesiae cathedralis Plocensis, morte et obitu Illustrissimi olim Joannis Gomolinski, episcopi Kiioviensis, huius scholasteriae ultimi et immediati possessoris, vacantem; bez wywodu przodków); tamże, ACapPloc 17, s. 29-30 (23 XI 1725: Installatio Perillustris Domini Martini Zatuski ad praelaturam decanatus in ecclesia cathedrali Plocensi post obitum Perillustris et Reverendissimi olim Ioannis Samplawski, decani cathedralis Plocensis, illius decanatus et praelaturae ultimi et immediati possessoris, vacantem; bez wywodu przodków); tamże, ACapPloc 19, k. 6v-7r (11 VII 1749: Installatio ad coadiutoriam praepositurae cathedralis Plocensis fundi Ducatus Sielunensis Illustrissimi Martini Zaluski, episcopi Drasnensis, suffraganei et decani Plocensis)

\section{0}

\section{Zatuski Pawet Antoni [biskup (Płock)]}

kanonik płocki (instalacja 16 VIII 1697) archidiakon pultuski (instalacja $8[?]^{77}$ IX 1709) ${ }^{78}$

${ }^{76}$ Korytkowski, Prałaci i kanonicy katedry metropolitalnej gnieźnieńskiej, t. 4, s. 430-434; Nowowiejski, Płock. Monografia historyczna, s. 80; Szostkiewicz, Katalog biskupów, s. 594; Encyklopedia wiedzy o jezuitach, s. 781; Nitecki, Biskupi Kościoła w Polsce, kol. (,dziekan płocki”); Prokop, Wypisy źródłowe do biografii polskich biskupów i opatów, cz. 4, s. 375-376 nr 108; Prokop, Biskupi w gronie prałatów i kanoników, s. 678; Przybyszewski, Katalog kanoników krakowskiej kapituly katedralnej, s. 250-251.

${ }^{77}$ Brak pewności co do daty dziennej.

${ }^{78}$ Nowowiejski, Płock. Monografia historyczna, s. 80; Szostkiewicz, Katalog biskupów, s. 594; 
ADP, ACapPloc 13, s. 309-310 (16 VIII 1697: Installatio Perillustris Domini Pauli Zatuski, thesaurarii domestici ac praelati curiae episcopi Plocensis, ad canonicatum fundi Kania post obitum Perillustris olim et Admodum Reverendi Alexandri Podkanski)

Perillustris et Admodum Reverendus Paulus Załuski ex illustrissimi familia, videlicet patre Andreae in Załuskie Załuski, stemmatis Junosza, matre Constantia de Konarzewo Konarzewska, stemmatis Pobog, avia paterna Petronella Bilinowna Stawska[?], stemmatis Lubicz, avia materna Marianna Dzierzanowska, stemmatis Gozdawa, est progenitus.

ADP, ACapPloc 15, k. 29r-v (Capitulum generale pro Festo Nativitatis Beatissimae Virginis Mariae cum continuatione dierum sequentium anno Domini 1709)

Comparens personaliter Perillustris et Reverendissimus Dominus Paulus in Załuskie Załuski, archidiaconus Pultoviensis, productis litteris installationis [...] ad archidiaconatum Pultoviensem post obitum et fata Illustrissimi olim et Reverendissimi Domini Constantini Zielinski, archiepiscopi Leopoliensis et archidiaconi Pultoviensis, illius ultimi et immediati posessoris, vacantem [...], petiit se [...] installari et [...] recepi, stallum in choro, vocem et locum in capitulo cum plenitudine iuris canonici dari et assignari. [...] [k. 29v] Et Perillustres et Admodum Reverendi Domini [praelati et canonici] [...] ipsum installari in et ad realem, actualem ac pacificam possessionem dicti canonicatus et praebendae admitti, stallum in choro, locum et vocem in capitulo cum plenitudine iuris canonici dari et assignari et in confratrem suum recepi, decreverunt.

\section{1}

Zamoyski Jerzy biskup (Chełm/Krasnystaw)

kanonik płocki (recepcja 2 V 1601) $)^{79}$

ADP, ACapPloc 8, k. 239v-240r (Anno Domini 1601, Sancti Sigismundi. Receptio Illustrissimi et Reverendissimi Domini, Domini Georgii Zamoyski, episcopi Chelmensis et abbatiae Cervenensis administratoris, ad canonicatum natum ecclesiae Plocensis praefatae abbatiae Cervenensis; bez wywodu przodków).

62

Zieliński Konstanty Józef [arcybiskup (Gniezno - Lwów) kanonik plocki (recepcja 4[?] ${ }^{80}$ V 1672)

Nitecki, Biskupi Kościoła w Polsce, kol. 507 (,,archidiakon pułtuski”); Prokop, Biskupi w gronie prałatów i kanoników, s. 678.

${ }^{79}$ Szostkiewicz, Katalog biskupów, s. 508; Folwarski, Poczet opatów klasztoru kanoników regularnych w Czerwińsku, s. 27-29; Nitecki, Biskupi Kościoła w Polsce, kol. 508; Prokop, Biskupi w gronie prałatów i kanoników, s. 664.

${ }^{80}$ Brak pewności co do daty dziennej. 
archidiakon pultuski (recepcja 25 IV 1681) ${ }^{81}$

ADP, ACapPloc 11, s. 33-34 (Capitulum generale pro festo Sancti Sigismundi anno Domini 1672: Receptio Perillustris Constantini Zielinski in canonicatum fundi Otolinko post mortem et obitum olim Perillustris et Admodum Reverendi Domini Vincentii Kraiewski, canonici, illius ultimi et immediati possessoris), s. 148-149 (25 IV 1681: Receptio Perillustris Constantini Zielinski in archidiaconum Pultoviensem)

Perillustris et Admodum Reverendus Constantinus Zielinski ex quatuor stemmatibus nobilibus parentibus natus est, videlicet patre Magnifico Ludovico Zielinski, castellano Sierpnensi, stemmatis Swinka, matre vero Magnifica Helena Zawadzka, Magnifici Ioannis Zawadzki, palatini Parnaviensis, filia, stemmatis Rogala, avia paterna Barbara Herburtowna, stemmatis Herburth, avia materna Anna Sewerynowna, stemmatis Złote Okno alias Szyba.

63

Żorawski (Żurawski) Michat [biskup (Płock)]

koadiutor-kanonik plocki (instalacja 11 II 1752) 82 $^{2}$

ADP, ACapPloc 19, k. 95r-96r (11 II 1752: Installatio Perillustris Michaelis Zorawski ad coadiutoriam canonicatus ecclesiae cathedralis Plocensis fundi Grochowo, possessionis vero Perillustris Domini Josephi Markowski, canonici cathedralis Plocensis; bez wywodu przodków)

ADP, ACapPloc 20, k. 73r-v (31 X 1754: Possessio Perillustri Zorawski); zob. również: tamże, ACapPloc 23, s. 627 (Capitulum septimanale 11 I 1782: Obitus Illustrissimi suffraganei Zorawski - sine testamento)

Cum Perillustris Zorawski, antea coadiutor canonicatus et praebendae in hac ecclesia cathedralis Plocensis fundi Grochowo Perillustris olim Josephi Markowski vita nuper functi nuntius mortis extiterit in praesenti capitulo, iuraque coadiutoriae suae cum futura successione ad eundem canonicatum reproduxerunt, et se post fata sui coadiuti in plenam possessionem canonicatus eiusdem recepi, stallum in choro, vocem activam et passivam in capitulo assignari et dari debita cum instantia petiit, Perillustres Domini praelati et canonici [] eundem Perillustrem Zorawski [] [k. 73v] in plenam possessionem dicti canonicatus receperunt et admiserunt.

${ }^{81}$ Korytkowski, Prałaci i kanonicy katedry metropolitalnej gnieźnieńskiej, t. 4, s. 481-492; Szostkiewicz, Katalog biskupów, s. 515; J. Wieteska, Katalog prałatów i kanoników prymasowskiej kapituly towickiej od 1433 do 1970 r., Warszawa 1971, s. 85-86; Nitecki, Biskupi Kościoła w Polsce, kol. 515 (,,archidiakon pułtuski”); Prokop, Biskupi w gronie prałatów i kanoników, s. 675.

${ }^{82}$ Nowowiejski, Płock. Monografia historyczna, s. 70, 80, 208, 614; Szostkiewicz, Katalog biskupów, s. 597; Żebrowski, Zarys dziejów diecezji płockiej, s. 64 nr 33; Nitecki, Biskupi Kościoła w Polsce, kol. 522; Prokop, Biskupi w gronie prałatów i kanoników, s. 684. 
Cieszejko Amand Wiktoryn biskup (Baków)
proboszcz kotomyjski (instytucja 11 IV 1696) (13 $^{83}$

AALw, K.K. 19[17], k. 336v-337r (11 IV 1696: Institutio Reverendissimi episcopi Bacoviensis ad ecclesiam parochialem Kotomyiensem)

Ad ecclesiam parochialem Kołomyiensem, morte et obitu Perillustris et Admodum Reverendi olim Alexandri Potocki, canonici Chelmensis, praepositi Sokalensis, illius ultimi et immediati possessoris, vacantem, Perillustris et Admodum Reverendus Joannes Thomas Josephowic, canonicus et iudex delegatus Leopoliensis, Sacrae Regiae Maiestatis secretarius, Reverendissumum Dominum Victorinum Cieszeyko, episcopum Baccoviensem in terra Moldaviae, ad praesentationem Serenissimi Joannis III., feliciter nobis regnantis, eiusdem ecclesiae legitimi patroni et collatoris, [...] in persona Reverendi Constantini Jacobi Grabowski, presbyteri, ipsius procuratoris, instituendum ac ivestiendum esse duxit.

\section{2}

\section{Czapski Tomasz Franciszek [biskup (Chełmża)]}

kanonik chetmiński (rezygnacja 13 VII 1702) ${ }^{84}$

ADPelp, Archiwum Kapituly Katedralnej Chetmińskiej, sygn. B I 3, k. 71 (Anno millesimo septingentesimo secundo, die vero Jovis decima tertia Julii, Mariaeburgi)

Coram Illustrissimo, Excellentissimo et Reverendissimo Theodoro Potocki, episcopo Culmensi et Pomesaniae, actisque praesentis consistorii personaliter constitutus Perillustris et Reverendissimus Franciscus Thomas Czapski, canonicus ecclesiae cathedralis Culmensis principalis, non coactus, non compulsus, nec aliqua fraude, dolo aut sinistra machinatione circumventus, sed palam sponte ac libere dictum canonicatum et praebendam, cuius hactenus legitimus et pacificus exstitit possessor, resignavit suamque huiusmodi resignationem admitti et beneficium vacare decerni actisque suis insinuari debita cum instantia postulavit. Et Illustrissimus supramemoratus, recepto prius a praedicto resignato corporali iuramento in eam rotam: quod in huiusmodi resignatione nulla intercesserit fraus, dolus, symoniaca labes aut aliqua illicita actio et corruptela, ad Sanctam Dei Evangeliam, eandem admisit [ac] canonicatum et praebendam [...] vacare delaravit.

${ }^{83}$ Szostkiewicz, Katalog biskupów, s. 426; Nitecki, Biskupi Kościoła w Polsce, kol. 57.

${ }^{84}$ R. Frydrychowicz, Geschichte der Cistercienserabtei Pelplin und ihre Bau- und Kunstdenkmäler, Düsseldorf [1905], s. 111-112 (nr 35); Diecezja chetmińska, s. 46-47 nr 43; A. Mańkowski, Prałaci i kanonicy katedralni chetmińscy, s. 24-25; Szostkiewicz, Katalog biskupów, s.428; Nitecki, Biskupi Kościoła w Polsce, kol. 62 („,kanonik chełmiński (1701)”); W. Zawadzki, Duchowieństwo katolickie oficjalatu pomezańskiego w latach 1525-1821, t. 2 - Stownik, Elbląg 2009, s. 44. 


\title{
Czulski Walentyn Konstanty [biskup (Chetm/Krasnystaw)] kanonik chetmski (instytucja 15 I 1687)
}

AALb, Rep.60 A 118, k. 6r-v (Actum Skierbieszoviae, die decima quinta Januarii anno Domini 1687․ Institutio Perillustris Domini Valentini Czulski, apostolici et causarum curiae suae notarii, ad canonicatum cathedralem Chelmensem doctoralem - dokument biskupa chelmskiego Stanisława Jacka Święckickiego)

\section{4}

\section{Delamars (De la Mars) Michat [biskup (Kamieniec - Chetm/Krasnystaw)] prepozyt tarnowski (instalacja 18 V 1715) ${ }^{86}$}

\begin{abstract}
ADT, KKol I 5, k. 194v-195r (18 V 1715: Perillustris Michael de la Mars ad praeposituram installatus); zob. również: tamże, k. 220v-221r (De vacante praepositura Tarnoviensi. Anno Domini $1725^{\text {to }}$, die $1^{\text {ma }}$ mensis Aprilis. Institutio ad praeposituram Tarnoviensem [...] vacantem post obitum et mortem piae memoriae Perillustris et Admodum Reverendi Michaelis de la Mars, episcopi Tricomiensis, suffraganei [pozostawiono puste miejsce na wpisanie nazwy diecezji], dictae praepositurae ultimi et immediati possessoris, [mediante decreto] manu Celsissimi principis episcopi Cracoviensis anno currenti die 29. mensis Martii Kielciis subscripto)
\end{abstract}

Ad instantiam Perillustris et Admodum Reverendi Michaelis Delamars, iuris utriusque doctoris, cantoris cathedralis Chelmensis, archidiaconi et officialis Lublinensis [...], per Illustrium et Admodum Reverendum Simonem Josephum Woytowski, canonicum Wislicensem, [...] plenipotentem, per Illustres et Magnificos Franciscum et Caietanum Amores comites in Tarnow, fratres inter se germanos, dictae praepositurae legitimos patronos praesentatus, mediante decreto Illustrissimi loci ordinarii [...] lato Lunae 13. mensis Maii [...], vigore huius installationis Illustris plenipotens petiit se in gremium suscepi, introduci et installari.

${ }^{85}$ Pawelec, Biskupstwo chetmskie, cz. [7], s. $21 \mathrm{nr} 5$ (,,archidiakon, wikariusz generalny i oficjał chełmski”); Szostkiewicz, Katalog biskupów, s.431; Nitecki, Biskupi Kościoła w Polsce, kol. 65 (,,archidiakon i oficjał chełmski”).

${ }^{86}$ F. Herzig, Katedra, niegdyś kolegatia w Tarnowie, wraz z krótka wzmianka o onnych kościotach tarnowskich, Tarnów 1900, s. 18, nr 23 (,doktor obojga praw, kanonik krakowski, kantor chełmeński [sic!], archidiakon, oficjał lubelski, pleban w Bełczycach, biskup trikomeński, sufragan krakowski [sic!]; prepozyt kolegiaty [w Tarnowie] od 18 V 1715 r. [do] 1725†”); Pawelec, Biskupstwo chetmskie, cz. [7], s. $22 \mathrm{nr} 6$ (,kantor chełmski, prepozyt tarnowski, oficjał i archidiakon lubelski”); Szostkiewicz, Katalog biskupów, s. 432-433; Nitecki, Biskupi Kościoła w Polsce, kol. 71; Prokop, Wypisy źródtowe do biografii polskich biskupów i opatów, cz. 4, s. 317 nr 7; Przybyszewski, Katalog kanoników krakowskiej kapituły katedralnej, s. 41-42 („otrzymał godność prepozyta infułata oraz wieczystego oficjała tarnowskiego (instytucja $10 \mathrm{~V} 1715 \mathrm{r}$.)"). 
Dubrawski Pawet Konstanty [biskup (Przemyśl)] dziekan przemyski (instalacja 28 VII 1699) ${ }^{87}$

AAPrz, Archiwum Kapituly Przemyskiej, rkp VIII, s. 320-321 (28 VII 1699: instalacja Pawta Konstantego Dubrawskiego na dziekanię w kapitule katedralnej w Przemyślu «post ascensum Illustrissimi, Excellentissimi et Reverendissimi Domini Ludovici Zatuski ad cathedram episcopalem Plocensem»); zob. również: tamże, s. 150 (podczas sesji kapitulnej w dniu 22 I 1691 r. dziekanię po zmarlym biskupie sufraganie przemyskim Janie Dębskim otrzymat Ludwik Bartłomiej Załuski); nadto: tamże, s. 31-32 (podczas sesji kapitulnej 4 XII 1687 r. prepozyturę w kapitule katedralnej przemyskiej otrzymat - po śmierci Marcina Zaleskiego - Teodor Andrzej Potocki, późniejszy biskup chetmiński, warmiński i na koniec arcybiskup gnieźnieński)

\section{6}

Gomoliński Jan Pawet [biskup (Kijów)]

proboszcz jaworowski (instytucja 17 II 1698) ${ }^{88}$

AALw, K.K. 19[17], k. 631r-v (17 II 1698: Institutio Perillustris Gomolinski ad ecclesiam parochialem Javoroviensem); zob. również: tamże, k. 623r-v (15 I 1698: Dilatatio institutionis Perillustris Gomolinski ad ecclesiam Javoroviensem)

Ad ecclesiam parochialem Javoroviensem, morte et obitu Perillustris et Admodum Reverendi olim Matthiae Erasmi Wąsowski, cancellarii ecclesiae metropolitanae Leopoliensis, illius ultimi ac immediati possessoris, vacantem, Perillustrem et Admodum Reverendum Joannem Gomolinski, Sacrae Theologiae doctorem, archidiaconum Plocensem, officialem generalem Gedanensem, per Serenissimum Augustum Secundum, regem Poloniae, praesentatum, Perillustris et Reverendissimus Dominus Joannes Skarbek [...], episcopus Marrochiensis, suffraganeus, custos, vicarius in spiritualibus et officialis generalis Leopoliensis [...], instituit ac investivit.

\section{7}

Keck Udalryk Jerzy opat (Tyniec)

kanonik waradyński (nominacja 7 VIII 1812) ${ }^{89}$

${ }^{87}$ Szostkiewicz, Katalog biskupów, s. 440; Nitecki, Biskupi Kościoła w Polsce, kol. 84 („dziekan kapituły przemyskiej").

${ }^{88}$ Zob. wyżej przyp. 28.

${ }^{89}$ P. Sczaniecki, Katalog opatów tynieckich, „Nasza Przeszłość” 49 (1978), s. 231-235 (zwł. s. 233-234). 
Archivio Segreto Vaticano, Archivi delle Rappresentanze Pontificie, Archivio della Nunziatura Apostolica in Vienna, vol. 215, k. 634r-635v (Collatio canonicatus Magnovaradinensis pro abbate Udalrico Georgio Keck - kopia dokumentu prezenty cesarskiej)

Nos Franciscus Primus, Divina favente clementia Austriae imperator [...], Galiciae et Lodomeriae rex [...], magnus dux Cracoviae [...], memoriae commendamus tenore praesentium significantes quibus expedit universis, quod nos benigne confisi in praeclaris virtutibus, singulari item doctrina et eruditione morumque probitate fidelis nostri Venerabilis Udalrici Georgii Keck, abbatis Benedictinorum monasterii Tyniecensis, quibus ipse insignitus et ornatus apus Maiestatem Nostram meruit comendari, eundem Udalricum Georgium Keck velut personam idoneam eximiisque qualitatibus instructam ac de Ecclesia Dei benemeritam nobisque hoc nomine gratam et acceptam, ad ultimum canonicatum cathedralis ecclesiae Latini ritus Magnovaradinensis per promotionem fidelis nostri nobis dilecti Reverendi nec non Spectabilis ac Magnifici comitis Ladislai Csàki de Keresztszegh, [...] electi episcopi Corczolensis [...] et dictae cathedralis ecclesiae Magnovaradinensis hactenus custodis et canonici [...], legitime vacantem [...][k. 634v], duximus eligendum, nominandum et praesentandum [...] immo eligimus, nominamus, praesentamus damusque et conferimus praesentium per vigorem. [...] Datum in archiducali civitate nostra Vienna Austriae, die septima mensis Augusti anno Domini millesimo octingentesimo duodecimo.

\section{8}

Kobielski Franciszek Antoni biskup (Włoctawek) [(- Kamieniec - Łuck)] scholastyk wloctawski (instytucja 24 XII 1725) $)^{90}$

ADW, 2-ABKP 28[44], k. 225r-v (24 XII 1725: Institutio ad scholasteriam Vladislaviensem Kobielski); zob. również: ADW, 2-ABKP 29[45] - Protocollum actorum 1726-1730, k. 4r-v (19 I 1726: Institutio ad ecclesiam parochialem Mevensem Franciscum Kobielski, episcopum Antinopolitanum, suffraganeum Vladislaviensem)

Illustrissimus et Reverendissimus Dominus Christophorus Antonius a Słupow Szembek, Dei et Apostolicae Sedis gratia episcopus Vladislaviensis et Pomeraniae, ad scholasteriam in ecclesia cathedrali Vladislaviensi post $[k .225 \mathrm{v}]$ mortem et obitum Perillustris et Reverendissimi olim Joannis Tarnowski, eiusdem scholasteriae ultimi et immediati possessoris vacantem, Illustrissimum et Reverendissi-

${ }^{90}$ Korytkowski, Prałaci i kanonicy katedry metropolitalnej gnieźnieńskiej, t. 2, s. 261-263; Chodyński, Biskupi sufragani włocławscy, s. 69-70 nr 30 (,scholastykiem [włocławskim] instalowany na kapitule generalnej w styczniu 1726 r.”); Szostkiewicz, Katalog biskupów, s. 486; Wieteska, Katalog prałatów i kanoników prymasowskiej kapituły łowickiej, s. 94-95; Królik, Kapituła kolegiacka w Warszawie, s. 191 nr 103; Nitecki, Biskupi Kościoła w Polsce, kol. 207 (,archidiakon włocławski (1732)"); Prokop, Sylwetki biskupów tuckich, s. 151-156; Prokop, Wypisy źródłowe do biografii polskich biskupów i opatów, cz. 4, s. 328-329 nr 27; Przybyszewski, Katalog kanoników krakowskiej kapituly katedralnej, s. 73-74. 
mum Franciscum Kobielski, episcopum Antinopolitanum, suffraganeum Vladislaviensem, [] instituendum ac investiendum esse duxit.

Komorowski Adam Ignacy [arcybiskup (Gniezno)]

kanonik tarnowski (instalacja 30 V 1743) ${ }^{91}$

\begin{abstract}
ADT, KKolI6, s. 26 [30] (AnnoDomini 1743 $3^{\text {tio }}$, die 30.mensis Maii); zob.również: tamże, s. 56[60]57[61] (sesja kapituly w dniu 3 XI 1750 r., podczas której ad canonicatum fundi Łukowa, post ascensum Illustrissimi Kumorowski [sic!] ad archiepiscopatum Gnesnensem et dignitatem primatialem vacantem, instalowany zostat Perillustris Kłosowski, secretarius Sacrae Regiae Maiestatis, którego reprezentowat mandatarius Illustris et Admodum Reverendus Luzarkiewicz, collegiatae Omnium Sanctorum Cracoviensis canonicus)
\end{abstract}

Celebratum est capitulum partiale, [...] in quo quidem capitulo comparens personaliter Perillustris [Johannes] Mietelski, archidiaconus Tarnoviensis, fecit relationem praesenti in capitulo, quod Illustrissimus Dominus Adamus Komorowski, ecclesiarum cathedralis Cracoviensis et collegiatarum Sancti Michaelis in Arce et Pilcensis praepositus et officialis perpetuus, per Magnificos Caietanum Amor, Josephum Amor et Didacum Gratus Tarnowskich, legitimos patronos et collatores, ad canonicatum fundi Łukowa, post mortem et obitum Perillustris Domini [Dominici] Sieniensky vacantem, sit praesentatus, et in curia Eminentissimi cardinalis episcopi Cracoviensis institutus, sed ob certas legalitates publicas in persona a sui ad installandum condescendere non valens nisi per plenipotentem, suae installationis actum expedire cupiens et volens, in quem finem verum et legitimum plenipotentem suum Perillustrem Mietelski, archidiaconum Tarnoviensem, constituit. Qui quidem Perillustris plenipotens, praesentantis plenipotentiae literis tumque reproducto instrumento institutionis memorati Illustrissimi Komorowski ex curia Eminentissimi, sub die Veneris 24. mensis Maii anno currenti Bodzantino emanatis, manu propria eiusdem Eminentissimi subscriptis sigilloque eiusdem communitis, sanis, salvis et illaesis, nomine principalis sui petiit se ad dictum canonicatum fundi Łukowa installari, introduci et in gremium suscipi. Et Venerabile Capitulum [...] eundem plenipotentem introducendum et installandum esse decrevit et ad eundem effectum Perillustrem [Albertum Kaszewicz] scholasticum et Josephum Niedzwiecki canonicum de medio sui deputavit.

${ }^{91}$ Korytkowski, Arcybiskupi gnieźnieńscy, prymasowie i metropolici polscy, t. 4, s. 573nn; Herzig, Katedra, niegdyś kolegatia w Tarnowie, s. $25 \mathrm{nr} 9$ (,kanonik krakowski, prepozyt, oficjał pilźnieński; kanonik [tarnowski prebendy] tytułu Rozesłania Apostołów, zwanej kanonią łukowską, od 30 V 1743 r. [do] 1750”); Szostkiewicz, Katalog biskupów, s. 486; Bukowski, Katalog opatów jędrzejowskich, s. 200-201 (,kanonik tarnowski (1724)”); S. Salaterski, Kolegiata i kapituła św. Matgorzaty P.M. w Nowym Sączu (1448-1791), Nowy Sącz 1997, s. 315-316; Nitecki, Biskupi Kościoła w Polsce, kol. 209-210 (,,kanonik tarnowski”); Prokop, Arcybiskupi gnieźnieńscy, s. 252-254; Prokop, Wypisy źródtowe do biografii polskich biskupów i opatów, cz. 4, s. 328-329 nr 28; Przybyszewski, Katalog kanoników krakowskiej kapituły katedralnej, s. 80-82. 
Lenczowski Jan biskup (Kraków [Lublin]) kanonik sandomierski (instytucja 6 III 1773) archidiakon sandomierski (instytucja 5 V 1773) ${ }^{92}$

AKMK, AEp 100, k. 1v-2r (Sabbathi VI Martii [1773], Varsaviae. Institutio Illustrissimi Lenczowski ad canonicatum Sandomiriensem Annuli Reginalis)

Celsissimus princeps, Illustrissimus et Reverendissimus Dominus Caietanus Ignatius Sołtyk, episcopus Cracoviensis, dux Severiae, ad canonicatum fundi Annuli Reginalis in ecclesia insigni collegiata Sandomiriensi, post liberam illius resignationem per Illustrem et Admodum Reverendum Stanislaum Minocki, utriusque iuris doctorem, canonicum Scarbimiriensem, in Zwoleń et Wielgie curatum, actorum curiae Suae Illustrissimae Celsitudinis notarium, dicti canonicatus immediatum possessorem, factam, vacantem, Illustrissimum et Reverendissimum Joannem Cantium Lenczowski, episcopum Abderitanensem, suffraganeum et officialem generalem Lublinensem, per Suam Regiam Maiestatem, dicti canonicatus legitimum et unicum patronum, praesentatum, instituendum ac investiendum esse duxit.

AKMK, AEp 100, k. 3r-v (Mercurii V Maii [1773], Cracoviae. Institutio Illustrissimi Lenczowski ad archidiaconatum Sandomiriensem)

Celsissimus princeps, Illustrissimus et Reverendissimus Dominus Caietanus Ignatius Sołtyk, episcopus Cracoviensis, dux Severiae, $[k .3 v]$ ad archidiaconatum insignis collegiatae Sandomiriensis, post fata Illustris Admodum Reverendi olim Joannis Radwanski, illius immediati possessoris, vacantem, Illustrissimum et Reverendissimum Joannem Cantium Lenczowski, episcopum Abderitanensem, suffraganeum suum et officialem generalem Lublinensem, canonicum Sandomiriensem, per capitulum eiusdem collegiatae, prout de iure electum et praesentatum, [...] instituendum ac investiendum esse duxit.

Ostaszewski Tomasz [biskup (Płock)]

proboszcz uchański (instytucja 16 IX 1772)

kanonik chetmski (instytucja 9 XI 1773) ${ }^{93}$

${ }^{92}$ Wiśniewski, Katalog prałatów i kanoników sandomierskich, s. 177-178; Szostkiewicz, Katalog biskupów, s. 504; Nitecki, Biskupi Kościoła w Polsce, kol. 243; Przybyszewski, Katalog kanoników krakowskiej kapituly katedralnej, s. 264-265.

${ }^{93}$ Receptiones seu installationes, s. 156 („,cuius pater erat Florianus Antonius Ostaszewski, thesaurarius Bracławiensis, armorum Ostoia, mater Marianna Bartołowna, de armis Grzymała, ma- 
AALb, Rep.60 A 136, s. $71-73$ (Varsaviae, 16 IX 1772: Institutio Admodum Reverendi Thomae Ostaszewski ac ecclesiam parochialem Uchanensem, diaecesis [C]hetmensis, post assecutionem alterius beneficii Igloviensis in Scepusio, tum abbatiae commendatariae Plocensis per Perillustrem ac Reverendissimum Dominum Joannem Karski, canonicum metropolitanum et nominatum suffraganeum Gnesnensem, illius ultimum et immediatum possessorem legittimum, vacantem), s. 209-211 (Varsaviae, 9 XI 1773: Institutio ad canonicatum cathedralem [C]hetmensem, post liberam resignationem Perillustris Reverendissimi Francisci Komornicki, [nominati suffraganei Luceoriensis], illius ultimi et immediatis possessoris, vacantem, Illustris Admodum Reverendi Thomae Ostaszewski, praepositi in Uchanie); zob. nadto: tamże, s. 212213

Piechowski Michat Stanisław [biskup (Przemyśl)]

kanonik skalbmierski (recepcja 1 V 1704) ${ }^{94}$

ADK, II KS-3, s. 20-21 (Anno millesimo septingentesimo quarto, die prima Maii, celebratum est capitulum particulare, [in quo facta est] receptio Illustris Michaelis Piechowski in canonicatum primae praebendae Scarbimiriensis); zob. równiez: tamże, s. 113 (sesja generalna 23 VI 1720 r., w zwiąku z która nieobecny na niej kanonik M. Piechowski wzmiankowany jest jako nominatus episcopus Gratianopolitanus, suffraganeus Praemisliensis)

Pro canonicatu praebendae primae vacante post liberam resignationem Illustris et Admodum Reverendi Francisci Szembek, producens provisionis apostolicae literas et institutionem factam per Perillustrem et Admodum Reverendum Thomam Szultz Prontnicki [Prątnicki], Culmensem generalem vicarium et praepositum eiusdem cathedralem ecclesiae [s. 21], eiusdem praefati Perillustris vicarii [generalis] Culmensis manu scriptam, legitimus plenipotentiarius Reverendus Silvester Więckowic dictus, primae praebendae vicarius et praepositus hospitalis Scarbimiriensis, petiit nomine sui principalis, Illustris Michaelis Piechowski, Romae degentis, quatenus in confratrem reciperet, locum in stallo obtineret ac ad omnia canonicatus et capituli iura et privilegia admitteret. Et Illustre Capitulum, visis

ter patris Elisabeth Klonowska, de armis Leszczyc, mater matris Barbara Skierkowska, de armis Jelita"); Nitecki, Biskupi Kościoła w Polsce, kol. 325.

${ }^{94}$ W. Szołdrski, Ks. Biskup Michat Piechowski, „Zapiski Towarzystwa Naukowego w Toruniu” 6 (1923), s. 188-190; T. Glemma, Źródta do dziejów kościelnych Pomorza w krakowskich archiwach diecezjalnych, [w:] Księga pamiątkowa 75-lecia Towarzystwa Naukowego w Toruniu, red. T. Czeżowski, Torun 1952, s. 61-62; Szostkiewicz, Katalog biskupów, s. 534; Z. Kratochwil, Sylwetki kapłanów z pomorskiego rodu Piechowskich, „Studia Pelplińskie” 9 (1978), s. 41-44; Nitecki, Biskupi Kościoła w Polsce, kol. 342 („,kanonik skalbmierski (1703)”); K. R. Prokop, Sakry pasterzy Kościoła przemyskiego w XVIII stuleciu, „Premislia Christiana” 12 (2006/2007), s. 175-177; Z.M. Joskowski, Biskupi z Ziemi Kaszubskiej. Stownik biograficzny, Banino 2008, s. 14-16 („12 IX 1703 r. otrzymał od papieża Klemensa XI godność kanonika i pierwszą prebendę kolegiaty św. Jana Chrzciciela w Skalbmierzu"). Por. nadto: Z. Kratochwil, H.I. Szumił, Kwerenda i praca badawcza nad genealogia rodu Piechowskich oraz historia niektórych klasztorów zakonu augustianów i kapucynów, „Archiwa, Biblioteki i Muzea Kościelne” 72 (1999), 14-16 (aneks 4). 
omnibus provisionis, installationis et plenipotentiae [litteris], eundem Illustrem Michaelem Piechowski, provisum apostolicum, pro confratre recepit, locum in stallo capitulari ad cornu epistolae designavit, ac ad omnes praerogativas admisit, salvis cappalibus, tandem in persona sua professionem fidelitatis et iuramentum solitum praestitit.

\section{3}

\section{Radoszewski (Radoszowski) Wojciech Józef [biskup (Kraków [Sandomierz])] prepozyt-infutat klimontowski (instytucja 22 VII 1776) dziekan opatowski (instytucja 19 IX 1789)95}

AKMK, AEp 100, s. 582[769]-584[771] (Lunae XXII Julii [1776], Cracoviae. Institutionis Boxa ad praeposituram infulatam Klimuntoviensem)

Coram iudicio curiae Celsissimi principis [...] episcopi Cracoviensis [...] [s. 583(770)] comparens personaliter Generosus Adalbertus Woynarowski, Illustris et Admodum Reverendi Adalberti Boxa Radoszowski, ecclesiarum insignis collegiatae Sandomiriensis canonici, parochialium in Osiek et Mydlow curati, ad ecclesiam praeposituralem infulatam Klimuntoviensem, post liberam resignationem Illustrissimi et Reverendissimi Joannis Karski, suffraganei Gnesnensis, illius ultimi et immediati possessoris, vacantem, per Illustrem Magnificum Franciscum Ledochowski, Vlodimiriensem capitaneum, eiusdem ecclesiae legitimum patronem, praesentati, actoris procurator [...], eundem ad dictam ecclesiam authoritate ordinaria institui ac investiri [...] [s. 584(771)] literasque institutionis ac investiturae in forma solita ex cancellaria officii praesentis extradi mandari postulavit. Judicum curiae [...] eundem [Adalbertum Boxa Radoszewski] ad supradictam ecclesiam praeposituralem infulatam Klimuntoviensem, modo praemisso vacantem, authoritate ordinaria instituendum ac investiendum esse decrevit, prout servatis de iure servandis instituit ac investi[v]it.

AKMK, AEp 117 - Acta actorum curiae episcopalis Cracoviensis annorum 1788 ${ }^{\text {vi }}$ [et] 1789, s. 1036[306]-1037 [307] (Sabbathi XIX Septembris [1789]. Institutio ad decanatum collegiatae Opatoviensis Illustrissimi Boxa Radoszowski)

Illustrissimus, Reverendissimus Dominus Josephus Olechowski, episcopus Uranopolitanus, suffraganeus, archidiaconus cathedralis Cracoviensis, auditor et iudex generalis Cracoviensis, Ordinis Sancti Stanislai eques, ad decanatum ecclesiae collegiatae Opatoviensis dioecesis Cracoviensis, morte Perillustris Admodum Reverendi Ludovici Krasinski, canonici cathedralis Camenecensis, illius ultimi et immediati possessoris, vacantem, Illustrissimum, Reverendissimum Dominum

${ }^{95}$ Wiśniewski, Katalog prałatów i kanoników sandomierskich, s. 243-246; Nitecki, Biskupi Kościoła w Polsce, kol. 373 („proboszcz w Klimontowie”); Przybyszewski, Katalog kanoników krakowskiej kapituly katedralnej, s. 266-267. 
Adalbertum Boxa Radoszewski, episcopum Hirinensem, suffraganeum Sandomiriensem, ad Tribunal Regni iudicem deputatum Cracoviensem, adhaerendo literis praesentationis favore illius a Celsissima Sophia principissa Lubomirska, castellana Cracoviensi, bonorum oppidi Opatow et aliarum haeredissa dictique decantus unica et legitima patrona, datis, emanatis, instituendum esse duxit, prout servatis de iure servandis institutit ac investivit.

\section{4}

Sienieński (Sieniński) Dominik Joachim [biskup (*)]

kanonik tarnowski (instalacja 21 III 1697) ${ }^{96}$

ADT, KKol I 5, k.116r-v (Anno Domini 1697mo, die vero $21^{\mathrm{ma}}$ Martii); zob. również: tamże, $k$. 173r (11 IX 1708: Dominicus de Sienno Sininski, ecclesiae Warmiensis, Tarnoviensis canonicus, praepositus infulatus Lascensis), k. 237r-v (9 IX 1728)

Illustris et Admodum Reverendus Dominus Dominicus Sininski [sic!], custos Vnieioviensis, electus et [przekreślone] institutus, in canonicatum fundi Łukowa concordibus votis *admissus* [wyraz nadpisany], per Illustrium et Admodum Reverendorum Dominorum capitularium, personaliter veniens, exhibuit literas institutionis ad praefatum canonicatum collegii Tarnoviense, quarum vigore petiit in Venerabile Capitulo in possessionem dicti beneficii se intromitti, installari, locum sibi in stallo et capitulo assignari. Et Venerabile Capitulum, visis literis installationis sub nomine et sigillo Perillustris et Reverendissimi infulati Tarnoviensis $[k$. $116 v]$ ex iudicio eiusdem collegiatae Tarnoviensis emanatis eundem esse introducendum, ac in possessionem eiusdem beneficii intromittendum decrevit, locum in stallo, vocem in capitulo, recepto prius ab eodem, iuxta praescriptionem constitu[tion] um capitularium, corporali iuramento, assignavit.

Sierakowski Wackaw Hieronim [arcybiskup (Inflanty/Wenden - Kamieniec - Przemyśl - Lwów)]

${ }^{96}$ Korytkowski, Prałaci i kanonicy katedry metropolitalnej gnieźnieńskiej, t. $492-499$ (,jako kanonik warmiński i tarnowski uzyskał prowizję apostolską na kanonię gnieźnieńską fundi Kłecko, do której wcielona była prepozytura infułacka kolegiaty łaskiej”); Herzig, Katedra, niegdyś kolegatia w Tarnowie, s. $25 \mathrm{nr} 8$ (,kanonik warmiński i gnieźnieński; kanonik [tarnowski prebendy] tytułu Rozesłania Apostołów, zwanej kanonią łukowską, od 21 III 1697 r. [do] 1743†”); Szostkiewicz, Katalog biskupów, s. 553; Słownik biograficzny kapituly warmińskiej, oprac. zbior., Olsztyn 1996, s. 225 (A. Kopiczko) („w 1697 r. otrzymał kanonię warmińską (instalacja 7 XI 1697 r.) i prawie w tym samym czasie kanonię tarnowską”); Nitecki, Biskupi Kościoła w Polsce, kol. 400 („,kanonik tarnowski”); Prokop, Wypisy źródłowe do biografii polskich biskupów i opatów, cz. 4, s. $353 \mathrm{nr}$ 70; Przybyszewski, Katalog kanoników krakowskiej kapituly katedralnej, s. 188-189 (,pierwszym beneficjum, jakie osiągnął, była kanonia tarnowska fundi Łukowa, na którą był instytuowany 15 III 1697 r.”). 
prepozyt jarostawski (instalacja 1 III 1735) ${ }^{97}$

AAPrz, 841, s. 76 (Capitulum partiale 1 III 1735)

In hoc partali capitulo, non obstante absentium quorumvis contumacia inchoata, constitutus personaliter Illustris Admodum Reverendus Dominus Valentinus Gosek, canonicus Jaroslaviensis, parochialis in Sieniawa curatus, Reverendissimi ac Perillustris Domini Venceslai Sierakowski, custodis coronarum Regni et canonici cathedralis Cracoviensis, ad praeposituram ecclesiae collegiatae Jaroslaviensis, morte et obitu Illustrissimi, Excellentissimi ac Reverendissimi olim Domini Alexandri Antonii de Pleszowice et Prędzel Fredro, episcopi Premisliensis, ultimi et immediati possessoris, vacantem [...], legitime inscriptus plenipotens [...], petiit nomine Reverendissimi Domini sui principalis in possessionem realem et actualem eiusdem praeposituram [...] sese induci et introduci, stallum in choro, locum et vocem in capitulo sibi assignari.

\section{6}

Skarbek Jan [arcybiskup (Lwów)] ～kanonik lwowski (instalacja 12 XI 1692)98

AALw, K.K. 18[16], k. 417v-418r (12 XI 1692: Institutio Perillustris Domini Skarbek ad canonicatum)

Ad canonicatum ecclesiae metropolitanae Leopoliensis, post liberam resignationem Perillustris et Admodum Reverendi Domini Antonii Stadnicki, illius ultimi et immediati possessoris, vacantem, Illustrissimus et Reverendissimus Dominus Constantinus comes in Lipe Lipski, Dei et Apostolicae Sedis gratia archiepiscopus Leopoliensis, abbatiae Andreoviensis administrator perpetuus, Perillustrem et Admodum Reverendum Dominum Joannem Skarbek, Sacrae Theologiae et iuris utriusque doctorem, per Serenissimum Joannem Tertium, regem Poloniae, magnum ducem Lithuaniae etc. etc., praedicti canonicatus legitimum patronum et collatorem, praesentatum, in contumaciam omnium et singulorum sua ex adverso ius et interesse putantium, literis cridae citat[i]onem, et non comparentium, instituendum ac investiendum esse duxit.

${ }^{97}$ Wiśniewski, Katalog prałatów i kanoników sandomierskich, s. 270-271; Szostkiewicz, Katalog biskupów, s. 554; Nitecki, Biskupi Kościoła w Polsce, kol. $401-402$ (,prepozyt jarosławski”); Prokop, Wypisy źródłowe do biografii polskich biskupów i opatów, cz. 4, s. 353-354 nr 71; Prokop, Biskupi kamienieccy, s. 287-297; Przybyszewski, Katalog kanoników krakowskiej kapituły katedralnej, s. 192-194.

${ }^{98}$ Szostkiewicz, Katalog biskupów, s. 555; Nitecki, Biskupi Kościoła w Polsce, kol. 404 („,kanonik i kustosz lwowski"). 


\section{7}

Szajowski Kasper [biskup (Gniezno)] prepozyt skalbmierski (instalacja 23 VI 1759) ${ }^{99}$

ADK, II KS-3, s.315 (23 VI 1759: Installatio Perillustris praepositi)

Illustris Gaspar Szajowski, insignis collegiatae Sandomiriensis canonicus coadiutor, ecclesiae parochialis in Solec praepositus, apostolicus et actorum capituli ecclesiae cathedralis Cracoviensis notarius, producta sui institutione ad praeposituram ecclesiae collegiatae Scarbimiriensis ex officio curiae Suae Illustrissimae Celsitudinis sub data Kielciis, Mercurii 13. mensis et anni currentis emanata, se ad eandem praeposituram admitti et installari postulavit. Venerabile Capitulum, viso authentico instrumento institutionis, dictum Illustrem Gasparum Szajowski installandum esse decrevit. [...] Qui Perillustris praepositus vocem tandem in capitulo obtinuit et iuramentum super statutis eiusdem capituli observandis et secretis non revelandis iuxta formam ritus Romani explevit.

\section{8}

Szembek Franciszek Antoni [biskup (Przemyśl)] kustosz przemyski (instytucja 1 X 1723) $)^{100}$

AAPrz, 69 - Acta actorum curiae Excellentissimi, Illustrissimi et Reverendissimi Domini, Domini Joannis in Stupow Szembek, [...] episcopi Praemisliensis [...], ab anno 1719 [ad annum 1724], k. 252r-v (1 X 1723: Institutio Reverendissimi Francisci Szembek ad custodiam cathedralem Premisliensem)

${ }^{99}$ Korytkowski, Prałaci i kanonicy katedry metropolitalnej gnieźnieńskiej, t. 4, s. 56-60; Wiśniewski, Katalog prałatów i kanoników sandomierskich, s. 287; Szostkiewicz, Katalog biskupów, s. 563; Salaterski, Kolegiata i kapituła św. Małgorzaty P.M. w Nowym Sączu, s. 339-340; Nitecki, Biskupi Kościoła w Polsce, kol. 426 (,prepozyt skalbmierski”).

${ }^{100}$ Korytkowski, Prałaci i kanonicy katedry metropolitalnej gnieźnieńskiej, t. 4, s. 62-63 („,syn Przecława Szembeka, kasztelana wojnickiego, starosty bieckiego, herbu Szembek, i Marii z Opoka Opockiej, kasztelanki wojnickiej, herbu Junosza; babkę po ojcu miał Zofię z Iwanowic Odrowążównę Pieniążek, starościankę biecką, herbu Odrowąż, po matce Marię Katarzynę z Marchowic Marchowicką, herbu Ostoja [...]; zanim został biskupem i sufraganem, piastował także godność kustosza przemyskiego"); Szostkiewicz, Katalog biskupów, s. 564; Wieteska, Katalog prałatów i kanoników prymasowskiej kapituly łowickiej, s. 90-91; Nitecki, Biskupi Kościoła w Polsce, kol. 429 („kantor przemyski”); Prokop, Wypisy źródłowe do biografii polskich biskupów i opatów, cz. 4, s. 355-356 nr 75; Przybyszewski, Katalog kanoników krakowskiej kapituly katedralnej, s. 214-215. 


\section{9}

Szeptycki Hieronim Antoni [biskup (Euck - Płock)]

prepozyt jaworowski (instytucja 29 XI 1737) ${ }^{101}$

AALw, K.K. 29[22], k. 522v-523r (29 XI 1737)

Illustrisssimus, Excellentissimus et Reverendissimus Dominus, Dominus Ignatius in Wyzyce Wyzycki, archiepiscopus metropolita Leopoliensis, ad ecclesiam praeposituralem Javoroviensem, post liberam resignationem Illustrissimi et Reverendissimi Josephi [Andreae] Załuski, referendarii Regni, illius ultimi et immediati possessoris, vacantem, Perillustrem et Reverendissimum Hieronymum Szeptycki, archidiaconum ecclesiae cathedralis Leopoliensis, per Serenissimum Augustum III., regem Poloniae, eiusdem praepositurae Javoroviensis legitimum patronum et collatorem, praesentatum, instituendum ac investiendum esse duxit.

\section{0}

Świrski Mikołaj biskup (Chetm/Krasnystaw)

prepozyt chetmski (instytucja 6 II 1649) ${ }^{102}$

AALb, Rep.60 A 113, k. 96v[28v]-97r[29r] (Institutio Illustris et Reverendissimi Domini Nicolai de Romanow Swierski ad praeposituram cathedralem Chetmensem per plenipotentem, Illustrem et Admodum Reverendum Dominum Christophorum Bakowski, decanum Chetmensem, Cracoviae, die 6. Februarii anno 1649); zob. również: tamże, k. 46r (Nominatio Admodum Reverendi Domini Nicolai Swierski ad suffraganeatum Chelmensem - dokument biskupa chetmskiego Pawła Piaseckiego z daty: Mogiła, 25 VI 1644 r.)

Illustrissimus et Reverendissimus Dominus, Dominus Stanislaus de Buzenin Pstrokonski, Dei et Apostolicae Sedis gratia episcopus Chełmensis, abbas Tinecensis, Admodum Illustrem et Reverendissimum Dominum Nicolaum Swierski, suffraganeum Chełmensem, praesentatum a Sacra Regia Maiestate ad praeposituram cathedralem Chełmensem, post mortem Illustris et Admodum Reverendi Domini Alberti Woysski, illius ultimi et immediati possessoris, vacantem, per suum plenipotentem ad hunc actum designatum, videlicet Illustrissimum et Admodum Reverendum Dominum Christophorum Bąkowski, decanum Chełmensem [], [k. 97r(29r)] per manus capiti sui plenipotentis praefati impeditionem, instituit ac investivit.

${ }^{101}$ Nowowiejski, Ptock. Monografia historyczna, s. 69, 85, 285, 508, 513; Szostkiewicz, Katalog biskupów, s. 565-566; Nitecki, Biskupi Kościoła w Polsce, kol. 432.

${ }_{102}$ Pawelec, Biskupstwo chetmskie, cz. [7], s. 18-20 nr 2; Szostkiewicz, Katalog biskupów, s. 568; Nitecki, Biskupi Kościoła w Polsce, kol. 442. 
Tyszkiewicz Jerzy biskup (Wilno) [(- Żmudź/Miedniki - Wilno)]
proboszcz koziegłówecki (rezygnacja 5 X 1626)

AKMK, AEp 43, k. 683r (Actum feria secunda, quae fuit dies quinta Octobris anno Domini 1626, Cracoviae. Resignatio parochialis ecclesiae in Koziegłowki); zob. również: tamże, $k$. $686 v$ (Cracoviae, 7 X 1626 - prowizja dla Jana Lackiego, kanonika kapitut kolegiackich kieleckiej oraz Wszystkich Świętych w Krakowie, na probostwo w Koziegłówkach «post liberam resignationem Domini Georgii Tyskiewic, suffraganei Vilnensis, vacantem»)

Coram Illustrissimo et Reverendissimo Domino Martino Szyszkowski, Dei et Apostolicae Sedis gratia episcopo Cracoviensi, ducis Severiae, constitutus personaliter Admodum Reverendus Dominus Stanislaus Rudzki, canonicus ecclesiae cathedralis Cracoviensis, praepositus Visliciensis, procurator et eo nomine Reverendissimi Domini Georgii Tyskiewic, suffraganei Vilnensis, exhibito mandato procuratorio palam et expressis verbis resignavit nomine principalis sui ecclesiam parochialem in Koziegłowki idque ob assecutionem episcopatus, petens hanc suam resignationem admitti et parochialem ecclesiam vacare decerni, offerendo se ad iuramentum quod in hac resignatione nulla fraus, dolus aut labas symoniaca intervenit. Et Illustrissimus et Reverendissimus Dominus [episcopus Cracoviensis], omisso iuramento ex certis causis, resignationem admisit parochialemque ecclesiam in Koziegłowki vacare decrevit.

\section{Zatuski Marcin (starszy) biskup (Ptock)} prepozyt jarosławski (recepcja 11 XI 1699) ${ }^{104}$

AAPrz, 841, s. 3-4 (Actus Venerabilis Capituli celebrati die undecima mensis Novembris anno millesimo sexcentesimo nonagesimo nono); zob. również: tamże, s. 11-12 (15 VI 1703: prepozytura jarosławskiej kolegiaty, wakujaca «post liberam resignationem [...] Martini de Zaluski Załuski [...], suffraganei Plocensis», przeszła na Jana Stanisława Metlant, kanonika kruszwickiego i audytora generalnego przemyskiego konsystorza biskupiego)

[Celebratum est capitulum partiale], in quo quidem partiali capitulo per pulsum maioris campanae debite intimato Illustrissimus et Reverendissimus Dominus Martinus Załuski, Dei et Apostolicae Sedis gratia episcopus Rosmensis, suffra-

${ }^{103}$ Szostkiewicz, Katalog biskupów, s. 576; Relationes status dioecesium in Magno Ducatu Lituaniae, t. 1 - Dioeceseos Vilnensis et Samogitiae, ed. P. Rabikauskas, Romae 1971, wg indeksu; Nitecki, Biskupi Kościoła w Polsce, kol. 458-459; V. Petkus, Vilniaus vyskupai Lietuvos istorijoje, Vilnius 2002, s. 397-425; Inskrypcje z wileńskich kościołów. Vilniaus bažnyčiu ịrašai, t. 1, pod red. W. Appla i E. Ulčinaitë, Vilnius 2005, s. 56-60 (nr 18); Prokop, Wypisy źródłowe do biografii polskich biskupów i opatów, cz. 4, s. 366-367 nr 93.

${ }^{104}$ Zob. wyżej przyp. 66. 
ganeus Plocensis, ad praeposituram istius ecclesiae collegiatiae [Jaroslaviensis] post liberam resignationem Illustrissimi et Reverendissimi Domini Ludovici [Załuski], eadem gratia episcopi Plocensis, sui germani, et praedictae praepositurae ultimi immediatique possessoris, per Illustrissimum Dominum Josephum Carolum Lubomirski, Curiae Regni mareschalcum, legitimum patronum et collatorem, praesentatus, canonice institutus et installatus post praestitum per ipsum super fidei Catholicae professionem tum quoque super statutis capitularibus solitam corporale ad Sancta Dei Evangelia iuramentum, [...] ad capitulum receptus [est]. 